\title{
A systems view of haloarchaeal strategies to withstand stress from transition metals
}

\author{
Amardeep Kaur, ${ }^{1,3}$ Min Pan, ${ }^{1,3}$ Megan Meislin, ${ }^{1}$ Marc T. Facciotti, ${ }^{1}$ Raafat El-Gewely, ${ }^{2}$ \\ and Nitin S. Baliga ${ }^{1,4}$ \\ ${ }^{1}$ Institute for Systems Biology, Seattle, Washington 98103-8904 USA; ${ }^{2}$ University of Tromso, 9037 Tromso, Norway
}

\begin{abstract}
Given that transition metals are essential cofactors in central biological processes, misallocation of the wrong metal ion to a metalloprotein can have resounding and often detrimental effects on diverse aspects of cellular physiology. Therefore, in an attempt to characterize unique and shared responses to chemically similar metals, we have reconstructed physiological behaviors of Halobacterium NRC-1, an archaeal halophile, in sublethal levels of $\mathrm{Mn}$ (II), $\mathrm{Fe}(\mathrm{II}), \mathrm{Co}(\mathrm{II}), \mathrm{Ni}(\mathrm{II}), \mathrm{Cu}(\mathrm{II})$, and $\mathrm{Zn}(\mathrm{II})$. Over $20 \%$ of all genes responded transiently within minutes of exposure to $\mathrm{Fe}(\mathrm{II})$, perhaps reflecting immediate large-scale physiological adjustments to maintain homeostasis. At steady state, each transition metal induced growth arrest, attempts to minimize oxidative stress, toxic ion scavenging, increased protein turnover and DNA repair, and modulation of active ion transport. While several of these constitute generalized stress responses, up-regulation of active efflux of $\mathrm{Co}(\mathrm{II}), \mathrm{Ni}(\mathrm{II}), \mathrm{Cu}(\mathrm{II})$, and $\mathrm{Zn}$ (II), down-regulation of Mn(II) uptake and up-regulation of Fe(II) chelation, confer resistance to the respective metals. We have synthesized all of these discoveries into a unified systems-level model to provide an integrated perspective of responses to six transition metals with emphasis on experimentally verified regulatory mechanisms. Finally, through comparisons across global transcriptional responses to different metals, we provide insights into putative in vivo metal selectivity of metalloregulatory proteins and demonstrate that a systems approach can help rapidly unravel novel metabolic potential and regulatory programs of poorly studied organisms.
\end{abstract}

[Supplemental material is available online at www.genome.org. The microarray data from this study have been submitted to GEO under accession nos. GSM109343-GSM109461 and GSM109514-GSM109522.]

Transition metals such as manganese (Mn), iron (Fe), cobalt (Co), nickel $(\mathrm{Ni})$ copper $(\mathrm{Cu})$, and zinc $(\mathrm{Zn})$ are essential cofactors in the physiology of all organisms. In fact, recent estimates suggest that over half of all proteins in every organism are metalloproteins (Degtyarenko 2000). Although essential in trace amounts, at higher levels these metals can be toxic to cells because they directly or indirectly compromise DNA, protein, and membrane integrity and function. For example, cycling in redox states of metals such as $\mathrm{Fe}$ and $\mathrm{Cu}$ and antioxidant scavenging by redoxinactive metals such as $\mathrm{Zn}$ can both cause oxidative damage to cell components through increased production of reactive oxygen species (ROS) (Nelson 1999). Organisms usually avoid metal toxicity through selective uptake, trafficking, and efflux of metal ions, enzymatic conversion of metals into non- or less-toxic redox states, or sequestering toxic metal ions with ferritins and metallothioneins (Silver 1992; Blindauer et al. 2002; Reindel et al. 2002; Zeth et al. 2004). These mechanisms are believed to be often regulated by free metal-ion concentration (Raab and Feldman 2003). In this regard, other factors such as salinity, $\mathrm{pH}$, temperature, and growth-medium components can all influence the metal stress response because they can alter effective free metal ion concentration in the cell (Babich and Stotzky 1980) or influence metal state (Nieto et al. 1989). However, recent studies have cast doubt on whether there is indeed sufficient intracellular free metal ions for metal sensors to directly bind and modulate metal uptake or efflux (Outten and O'Halloran 2001). If so,

\footnotetext{
${ }^{3}$ These two authors contributed equally to this work.

${ }^{4}$ Corresponding author.

E-mail nbaliga@systemsbiology.org; fax (206) 732-1299.

Article published online before print. Article and publication date are at http:// www.genome.org/cgi/doi/10.1101/gr.5189606.
}

then protein-protein interactions between metalloproteins and metallochaperones have been proposed to play a more prominent role in metal trafficking (metal sensing and allocation) than previously appreciated (Tottey et al. 2002). In fact, defects in metal trafficking can cause serious medical conditions including Wilson's and Menkes' disease (Andrews 2002). Therefore, understanding mechanisms for in vivo trafficking of transition metals and their specific allocation to metalloproteins remains a key goal.

It has been proposed that transcriptional responses could serve as a proxy for deciphering in vivo metal specificity of metalloregulators (Tottey et al. 2005). The reasoning being metal ion binding modulates transcription factor activity, thereby resulting in change in gene expression (Tottey et al. 2005). However, to decipher metal-protein speciation from transcriptional responses, one would require knowledge of both genes that respond to a specific metal and the metalloregulatory protein that directly mediates this control. This is further complicated by the fact that transcriptional responses induced by transition metals are a complex mix of direct consequences associated with reversing damage and indirect cellular adjustments necessary for maintaining homeostasis (Moore et al. 2005). Unlike a reductionist approach, a systems approach enables full appreciation of a global stress response of this type, thereby providing insights that help distinguish putative direct changes from indirect responses (Baliga et al. 2002, 2004). In a systems approach, changes at all informational levels (mRNA and protein levels, protein-protein and protein-DNA interactions, protein modifications, etc.) during a cellular response are measured and analyzed simultaneously in context of the relevant environmental perturbations. The goal is to formulate predictive models-mathematical and/ or descriptive that can both describe previous observations and 
also predict how a cell would react to an environmental perturbation (input), appropriately process information (e.g., via gene regulatory network[s]), and elicit a response (output). The model is refined by testing these predictions through additional rounds of systems analyses of targeted genetic and environmental perturbations (Facciotti et al. 2004). An ideal candidate for such global analysis is Halobacterium NRC-1, an archaeon that thrives in a $>4.0 \mathrm{M}$ salinity environment. This halophile is easily cultured and manipulated in the laboratory and has a range of systems-analysis tools available for its inquiry (Weston et al. 2003).

In this report, we describe systems level responses of Halobacterium NRC-1 to six transition metals ( $\mathrm{Mn}[\mathrm{II}], \mathrm{Fe}[\mathrm{II}], \mathrm{Co}[\mathrm{II}]$, $\mathrm{Ni}[\mathrm{II}], \mathrm{Cu}[\mathrm{II}]$, and $\mathrm{Zn}[\mathrm{II}])$ and an Fe-specific chelator (2, $2^{\prime}$ dipyridyl: DIP). Numerous biological insights were discovered through an integrated analysis of mRNA level changes for all genes in 66 steady-state and time-series experiments, simultaneously with 2187 protein functional associations, $\sim 6000$ protein-DNA interactions and phenotypic analyses on wild-type, and 17 gene knockout strains representing three function categories $(A B C$ transporters [five genes], $\mathrm{P}_{1}$ ATPases [two], and transcription regulators [five]) and a few miscellaneous categories (transposase [one], redoxin [one], putative siderophore biosynthesis [one], and unknown functions [two]). Among the key resistance and regulation mechanisms that were discovered in this study, we provide experimental evidence for roles of (1) two $\mathrm{P}_{1}$ ATPases, ZntA and YvgX, in Co(II), Ni(II), Cu(II), and Zn(II) resistance; (2) $\mathrm{Cu}$-dependent up-regulation of $\mathrm{Cu}(\mathrm{II})$-specific $\mathrm{P}_{1}$ ATPase $\mathrm{YvgX}$ by $V N G 1179 C$, a Lrp family regulator with a putative metal-binding TRASH domain (Ettema et al. 2003) in Cu(II) resistance; and (3) $\mathrm{Mn}$ (II)-dependent repression of active Mn(II) uptake by the MntR family regulator SirR in $\mathrm{Mn}$ (II) resistance. We also demonstrate that analysis of global transcriptional responses may indeed provide insights into in vivo metal selectivity for metalloregulatory proteins. Finally, we provide a synthesis of all our findings into a systems scale model of transition metal response. Thus, we demonstrate that a systems approach enables, in a relatively short period of time, detailed reconstruction of whole-cell physiological responses to complex environmental perturbations.

\section{Results and Discussion}

We present the results and discussion in six sections. Starting with metal-induced phenotypes of Halobacterium NRC-1 (Section 1 ), we subsequently reconstruct metal-induced physiological responses through analysis of steady-state and time-course transcriptional changes in all genes (Section 2) and describe putative regulatory mechanisms responsible for mediating these responses (Section 3). We then analyze similar responses to different metals and discuss it in the context of metal selectivity of key metalloregulatory proteins (Section 4). All observations and key findings are synthesized into a systems-level model of transition metal response (Section 5), and we conclude by reflecting on the overall implication of using a systems approach to characterize less-studied organisms (Section 6).

\section{Section 1: Phenotypic analysis}

\section{Halobacterium halts growth at higher concentrations of transition metals}

As little was known regarding Halobacterium NRC-1 transition metal response, we first characterized its growth phenotype in the presence of different concentrations of each of the six transition metals as described in the Methods (Fig. 1). Fe(II), Co(II), $\mathrm{Ni}(\mathrm{II})$, and $\mathrm{Zn}$ (II) mildly stimulated growth at lower concentrations, suggesting a deficiency of these metals in the standard Halobacterium growth medium. At higher concentrations, all metals were growth inhibitory (Fig. 1). Metal susceptibility varied by orders of magnitude; for example, $\mathrm{Zn}$ (II) inhibited growth at $0.05 \mathrm{mM}$, whereas Fe(II) was inhibitory between 7.5 and $8.5 \mathrm{mM}$. Effective inhibitory concentrations for other metals were as follows: $\mathrm{Co}(\mathrm{II}): 0.6 \mathrm{mM}$; $\mathrm{Cu}$ (II): $1.2 \mathrm{mM} ; \mathrm{Mn}$ (II): $2 \mathrm{mM}$, which is consistent with experimentally measured intracellular $\mathrm{Mn}(\mathrm{II})$ levels in Halobacterium sp. (Medicis et al. 1986); and Ni(II): 1.5-2 $\mathrm{mM}$. These observed growth defects were demonstrated to be a result of growth inhibition and not killing by each of the six metals (Supplemental Fig. 1). This growth-arrest phenotype is perhaps one of many mechanisms in Halobacterium NRC-1 to resist regular occurrence of stressful conditions in its dynamic hypersaline environment (Kennedy et al. 2001). However, it remains to be understood whether a specific regulatory mechanism is responsible for eliciting growth arrest or whether it is an indirect consequence of system failure due to unusually high metal ion stress.

\section{Section 2: Systems-level interrogation of metal response}

\section{Steady-state analysis of transcriptome changes in subinhibitory concentrations of transition metals}

Using microarray analysis, we investigated transcript level changes for all 2400 genes in Halobacterium NRC-1 exposed for 5 $\mathrm{h}$ to at least three concentrations of each metal (Fig. 1). The total RNA from each metal-exposed culture was compared with a universal RNA standard prepared from a culture of Halobacterium $N R C-1$ grown under defined conditions $\left(37^{\circ} \mathrm{C}, 220 \mathrm{rpm}\right.$ shaking, starting $\mathrm{OD}_{600}=0.05$, final $\mathrm{OD}_{600}=0.5-0.7$ ). The common reference RNA enables comparison across responses to different metals. Statistical significance of mRNA level changes were evaluated with maximum likelihood analysis (Ideker et al. 2000); biological and technical variation within total RNA from identically grown cultures was also previously investigated (Baliga et al. 2004). mRNA level changes discussed below are restricted to only those genes that changed in a statistically significant manner (see Methods for a brief discussion on choosing appropriate $\lambda$ values for assessing significance) in at least one condition. Overall, $\mathrm{Mn}(\mathrm{II})$ resulted in maximal change in terms of numbers of differentially regulated genes followed by $\mathrm{Zn}$ (II) and Fe(II). Co(II) and $\mathrm{Ni}$ (II) resulted in the least number of changes. For each metal, maximal transcriptional change occurred at a stimulatory or partially inhibitory concentration (Supplemental Table 1), emphasizing the importance of dose-titration to best study responses to environmental perturbations.

\section{Transcriptional change in over $20 \%$ of all genes within $25 \mathrm{~min}$ of exposure to $6 \mathrm{mM} \mathrm{Fe}(\mathrm{II})$ indicates an immediate large-scale physiological adjustment}

We investigated the rapidity with which a global metal response is elicited and also whether the steady-state analysis had potentially missed early transitory changes by conducting time-course analysis of response to $6 \mathrm{mM}$ Fe(II) (Fig. 2). This experiment was conducted in a chemostat to minimize unintended perturbations during sampling over the 320-min time course, and factors such as $\mathrm{pH}$, dissolved oxygen tension, cell density, and temperature 


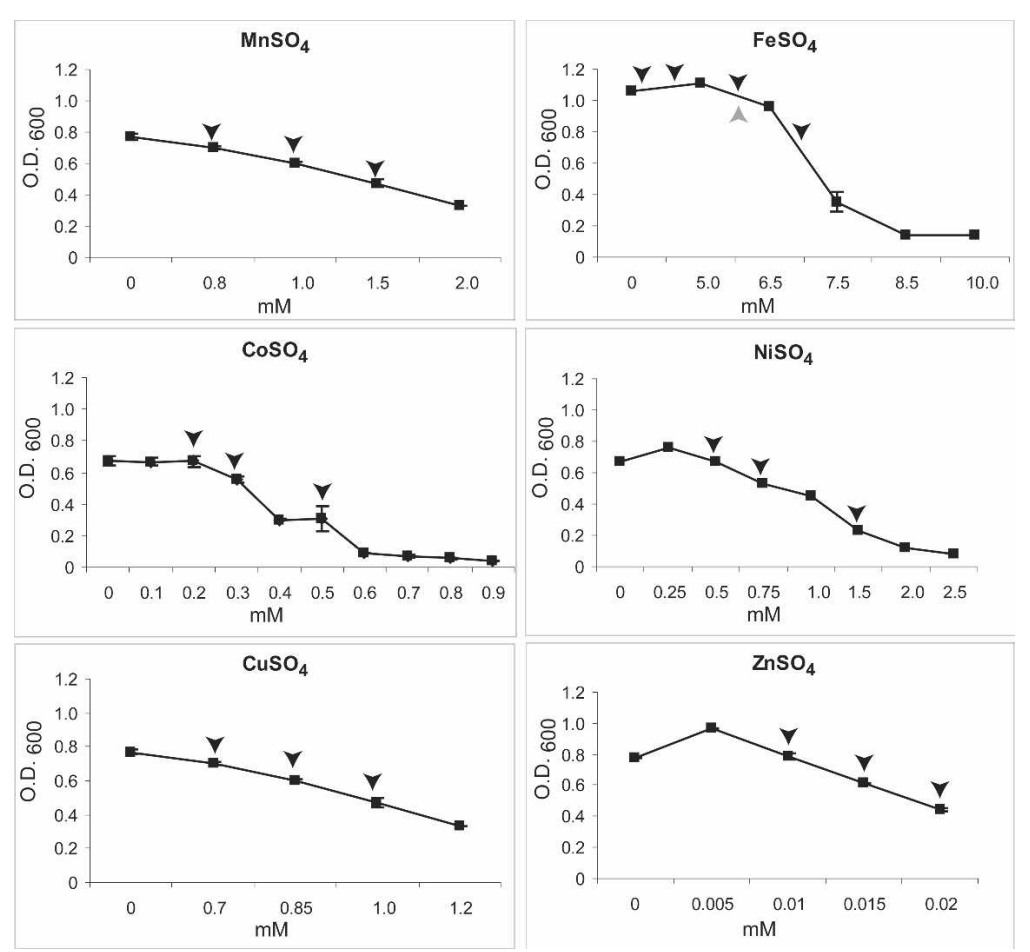

Figure 1. Effect of six transition metals on growth of Halobacterium NRC-1. The average of at least three independent biological replicates is shown. The bars represent standard error. The black arrowheads above each curve indicate concentrations at which microarray analyses were conducted. The gray arrow in the Fe curve indicates concentration used for time course analysis.

aids in reconstruction of the physiological state after prolonged exposure to transition metals.

\section{Integrated analysis of diverse systems biology data enables reconstruction of steady-state physiological response to fluctuations in metal concentration}

We reconstructed the physiological response of Halobacterium NRC-1 to transition metal stress through simultaneous analysis of transcript level changes (Supplemental Table 2) along with a variety of orthogonal datatypes, such as gene/protein functional associations (operons) (Moreno-Hagelsieb and Collado-Vides 2002), phylogenetic profile (Pellegrini et al. 1999), chromosomal proximity (Overbeek et al. 1999), physical interactions (protein-DNA interactions) (M.T. Facciotti, M. Pan, A. Kaur, M. Vuthoori, D.J. Reiss, R. Bonneau, P. Shannon, S. Donahoe, L. Hood, and N.S. Baliga, in prep.), putative functions in the SBEAMS database (http://halo.systemsbiology.net) (Bonneau et al. 2004), along with supporting evidence, such as matches in protein databank (PDB) (Sussman et al. 1998), protein families (Pfam) (Bateman et al. 2000), COG database (Tatusov et al. 2000), and metabolic pathways (KEGG) (Kanehisa 2002). All

were monitored and held constant. Transcription of altogether 623 genes was significantly perturbed in this experiment, of which mRNA levels of 452 genes ( $69 \%)$ changed within $0-25$ min and 413 of these early mRNA changes returned to preperturbation levels in 25-40 min. At $320 \mathrm{~min}$, the cell state was comparable to that captured at $300 \mathrm{~min}$ in the steady-state experiment (Fig. 2B,C). It is also noteworthy to mention that 129 mRNA level changes were shared between the time-course and steady-state experiments. Among the early changes were regulators (e.g., $t f b B$ and sirR), transporters (e.g., zntA, phosphate transport genes, peptide transport), ribosomal protein genes, and protein export. Early up-regulation of transcription and translation may serve two purposes, i.e., replacement of damaged transcripts and proteins and synthesis of new proteins necessary for handling metal stress and acclimatizing to the new environment.

Several previous systems-level studies have interpreted discrepancy in protein and mRNA levels as a possible outcome of post-transcriptional regulation (Ideker et al. 2001; Baliga et al. 2002). Given the scarcity of global measurements in terms of both time-resolution and dynamic range, this is a tenuous interpretation. In fact, it was clear from temporal analysis of the Fe(II) response that important early mRNA level changes were transitory and not present at equilibrium. The likely explanation is that the early transitory mRNA level changes result in sufficient protein to set up a cascade of events for transforming cell state into one appropriate for the new environment. If so, then measurements relatively late in the response are likely to capture higher protein concentrations for the same seemingly unchanged mRNAs that did indeed experience transitory upregulation early on in the response. While these transitory changes are important in deciphering the cascade of events during a stress response, analysis of mRNA changes at steady state of these analyses were conducted using the open-source software framework Gaggle (Shannon et al. 2006) (see Supplemental materials for details). We have also conducted extensive genedeletion analyses to evaluate whether changes in key functions were directly associated with minimizing metal toxicity (Supplemental Table 3). Below we discuss important findings from this physiological reconstruction.

Reactive Oxygen Species constitute a major component of transition metal stress One-hundred ninety four of the total 525 transcriptional changes elicited by the various transition metals were related to oxidative stress management, including dehydrogenases (NADH and succinate dehydrogenase $[\mathrm{SDH}]$ complexes, aldehyde reductase, peroxidase, etc.), ion scavenging systems (thioredoxin/ thioredoxin reductase and glutaredoxin), protein turnover (15 proteases and nearly all 53 ribosomal protein and nine translation factors), and 21 DNA replication, repair, and recombination genes (Supplemental Table 2). Overall, these observations are consistent with the property of transition metals to catalyze production of reactive oxygen species (ROS) (Haber and Weiss 1934; Winterbourn 1995; Kehrer 2000; Ercal et al. 2001; Valko et al. 2005), which are eliminated through the action of catalases and dehydrogenases (Mittler 2002; Sunkar et al. 2003). In fact, the time-scale analysis of $\mathrm{Fe}(\mathrm{II})$ response indicated rapid production of ROS, because genes for protein turnover responded within 5-25 min (Fig. 2).

In terms of numbers of oxidative stress management systems induced, $\mathrm{Mn}$ (II) and $\mathrm{Zn}$ (II) seemed to be most damaging. In fact, $\mathrm{Zn}$ (II) seemed to cause the most oxidative damage to proteins considering up-regulation of nearly three to four times as many protease/proteasome-encoding genes relative to that induced by other metals. This is not surprising knowing that excess $\mathrm{Zn}$ (II) can induce formation of ROS (Takeyama et al. 1995) and 


\section{A. Transcriptional changes in key function categories during Fe response}

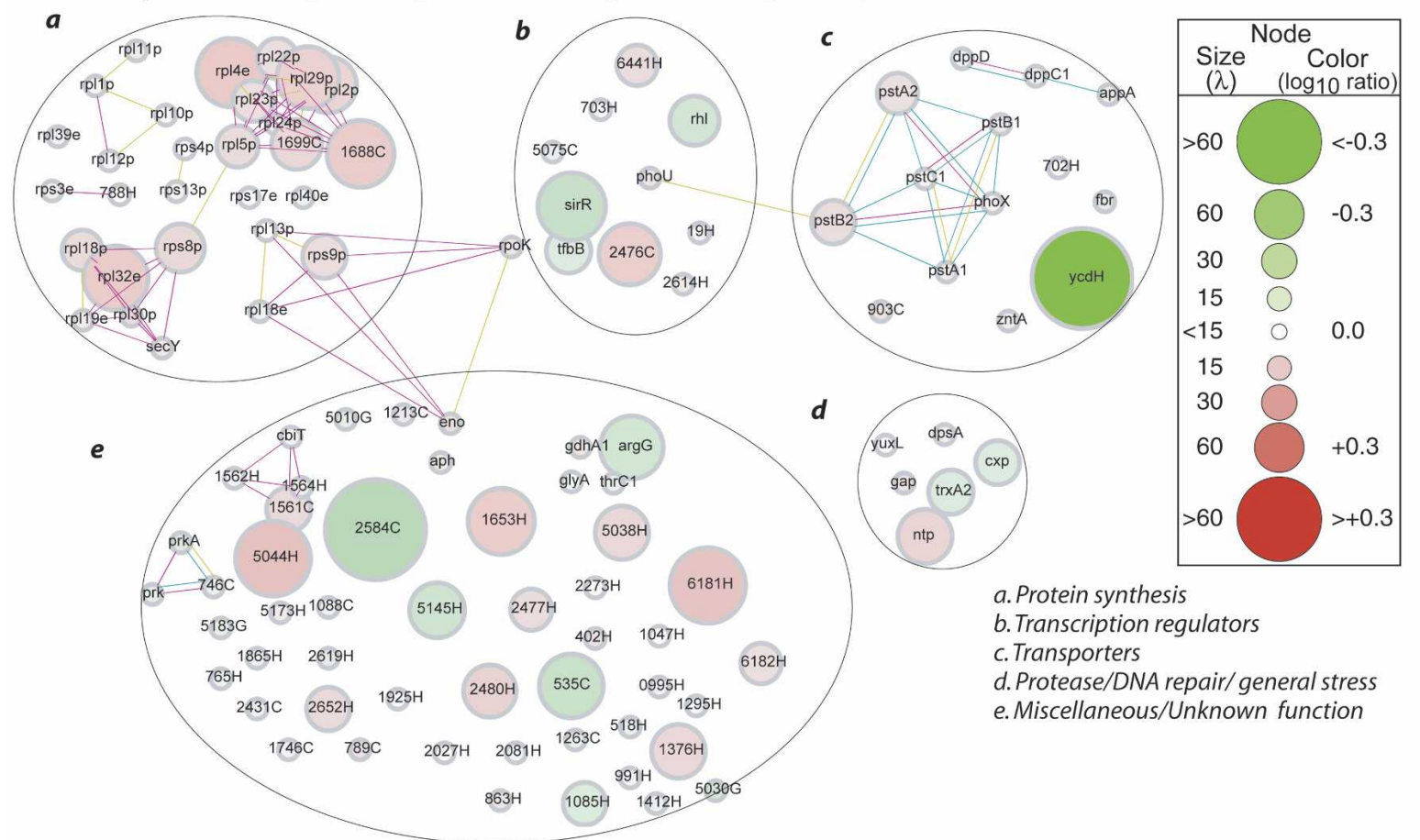

\section{B. Steady State (300min)}

$2 \mathrm{mM}$

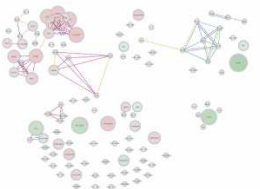

C. Time series
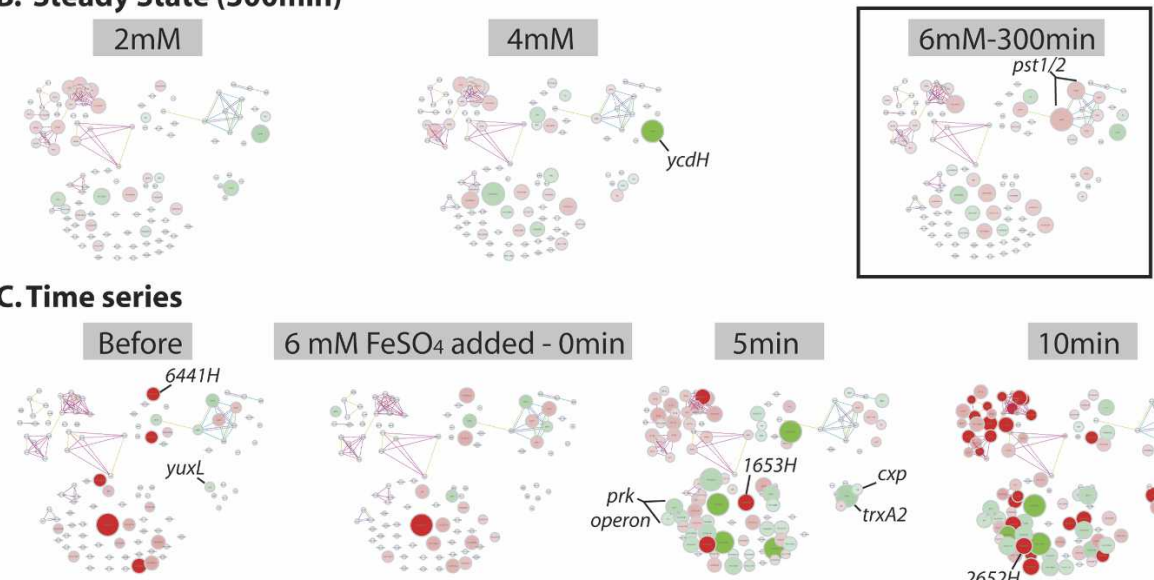

$5 \min$
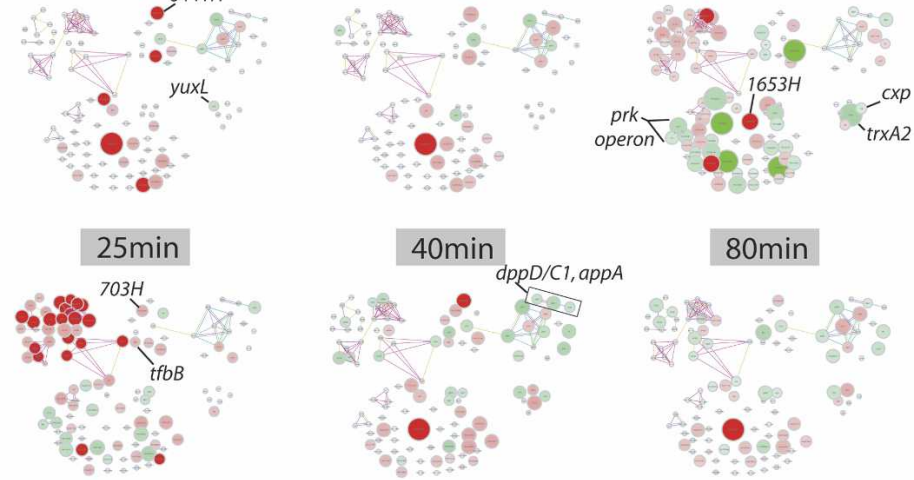

$80 \mathrm{~min}$

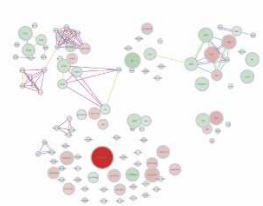

$10 \mathrm{~min}$

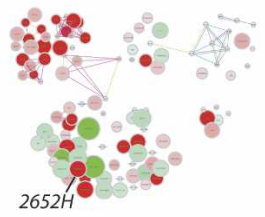

$160 \mathrm{~min}$

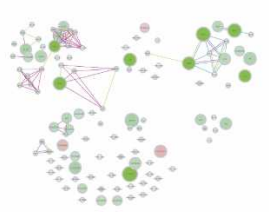

$7 \mathrm{mM}$

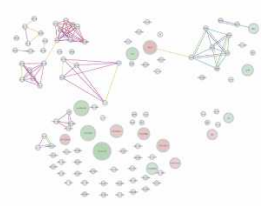

$15 \mathrm{~min}$

Figure 2. Dose and time dependence of response to Fe. (A) Steady-state response to $4 \mathrm{mM} \mathrm{Fe}(\mathrm{II})$ is used to describe the layout of this figure-use this as a key while viewing $B$ and $C$. Genes of key function categories (a-e; see inset key) that experienced mRNA level changes in a dose and/or time-dependent manner to Fe(II). Genes are indicated as circular nodes connected by three types of functional associations: operon (pink), chromosomal proximity (green), and phylogenetic pattern (blue). Red shading of nodes indicates increased mRNA and green shading denotes decreased mRNA concentration relative to concentrations in a standard reference RNA sample (see inset key). (B) Transcript level changes at 300 min in four concentrations of $\mathrm{FeSO}_{4}$. Relative mRNA levels were measured subsequent to 300 -min exposure at $37^{\circ} \mathrm{C} \mathrm{(220} \mathrm{rpm} \mathrm{shaking)} \mathrm{of} \mathrm{mid-logarithmic} \mathrm{growth} \mathrm{phase}$ halobacterial cultures to $2,4,6$, or $7 \mathrm{mM} \mathrm{FeSO}_{4}$. (C) Time-course mRNA level changes during response to Fe stress. A continuous culture of Halobacterium NRC-1 was subjected to sudden exposure to $6 \mathrm{mM} \mathrm{FeSO}_{4}$. mRNA levels were measured by microarray analysis just prior to addition of FeSO ${ }_{4}$ and over a nine-point time course up until 320 min. 
Systems analysis of transition metal response

inhibit key enzymes including $\mathrm{Cu} / \mathrm{Zn}$ superoxide dismutase, thioredoxin reductase (Gavella et al. 1999), DNA glycosylase, and endonuclease (Torriglia et al. 1997). For this reason, intracellular Zn(II) levels are tightly regulated (Chimienti et al. 2001), and in Halobacterium NRC-1 it was indeed the most toxic among all metals (Fig. 1).

\section{Metal-specific responses of metalloenzymes, a ferritin, and putative siderophore} biosynthesis genes

As mentioned earlier, transition metals play central roles in an array of central biological processes. Indeed, several metabolic pathways that require metal cofactors were differentially regulated during metal stress. An excellent example that illustrates this is Co(II)-specific down-regulation of four of seven genes encoding a segment of the pathway that requires this metal ion. Included among these genes is CobN, a putative Co-chelatase, which inserts Co into the corrin ring. This suggests that the normal culture medium for Halobacterium $N R C-1$ is deficient in $\mathrm{Co}(\mathrm{II})$, requiring higher concentrations of the chelatase to ensure appropriate trafficking of this metal ion. This is consistent with the mild stimulation of growth we observed with lower concentrations of $\mathrm{Co}(\mathrm{II})$ (Fig. 1). Likewise, responses of Zn-binding aldehyde reductase, Mo-cofactor biosynthesis genes, plastocyanin, etc., are also illustrative of underlying reasons for the farreaching effects of metal stress. Increase in $d p s A$ transcript during $\mathrm{Fe}(\mathrm{II})$ stress, on the other hand, in conjunction with its property to store iron in its nontoxic Fe(III) form (Reindel et al. 2002; Zeth et al. 2004), points to a regulatory mechanism that ensures increased abundance of DpsA to minimize Fe(II) toxicity, as has been reported for other prokaryotes (Munro and Linder 1978; Theil 1987; Nair and Finkel 2004; Wiedenheft et al. 2005). While DpsA takes care of excess Fe(II), low molecular-weight compounds termed siderophores are utilized by bacteria to scavenge Fe when its supply is limited (Winkelmann 2002). None of the putative siderophore biosynthesis genes ( $g a b T, b d b$, iucA, iucB, $h x y A$, and $i u c C$ ) in Halobacterium NRC-1 were differentially regulated in the presence of Fe(II), suggesting the Halobacterium culture medium has sufficient Fe, but intriguingly, addition of $\mathrm{Mn}$ (II) resulted in up-regulation of these genes, suggesting it might simulate Fe deficiency (this is discussed further in Section 4).

\section{Efflux of metal ions by $P_{1}$ ATPases is a key mechanism to minimize toxicity} of $\mathrm{Co}(I I), \mathrm{Ni}(I I), \mathrm{Cu}(I I)$, and $\mathrm{Zn}(\mathrm{II})$

Among systems known to actively transport metals, we investigated the $\sim 58 \mathrm{ABC}$ transport genes and three efflux ATPases that were differentially regulated by some or all metals. While results and discussion on $\mathrm{ABC}$ transport systems is provided in the Supplemental materials, here we will focus on $\mathrm{P}_{1}$ ATPases, which affect active efflux of transition metals (Rensing et al. 1999). Among the three putative $\mathrm{P}_{1}$ ATPases ( $c p x, z n t A$, and $\left.y v g X\right)$ in Halobacterium NRC-1, cpx was down-regulated in $\mathrm{Fe}(\mathrm{II}), \mathrm{Cu}(\mathrm{II})$, and $\mathrm{Ni}(\mathrm{II})$, and the other two ATPases were specifically upregulated by $\mathrm{Cu}$ (II) and/or $\mathrm{Zn}$ (II) (Supplemental Table 2). We investigated the consequence of deleting each of the two upregulated $\mathrm{P}_{1}$ ATPases on susceptibility to various metals. While $\Delta y v g X$ had defective growth only in $\mathrm{Cu}$ (II) (Fig. 3C; Supplemental Table 3; Supplemental Fig. 3i), $\Delta z n t A$ grew poorly in Co(II), Ni(II), $\mathrm{Cu}(\mathrm{II})$, and $\mathrm{Zn}$ (II) (Fig. 3; Supplemental Table 3; Supplemental Fig. 3iii). Thus, ZntA and $\mathrm{YvgX}$ together appeared to account for efflux of $\mathrm{Co}(\mathrm{II}), \mathrm{Ni}(\mathrm{II}), \mathrm{Cu}(\mathrm{II})$, and $\mathrm{Zn}(\mathrm{II})$. However, neither efflux system alone was sufficient for conferring tolerance to $\mathrm{Cu}$ (II) stress. Multiple $\mathrm{Cu}$ (II)-resistance mechanisms in a single organism is not unusual. In Escherichia coli, for example, the P-type
ATPase CopA, the Cu-oxidase $\mathrm{CueO}$, and multicomponent $\mathrm{Cu}$ transport system CusCFBA are all required for clearing $\mathrm{Cu}$ (II) from the cells and reducing its toxicity (Grass and Rensing 2001). Finally, the broad specificity of ZntA is believed to be related to its charge and ligand preference of soft metal ions and not their size (Hou and Mitra 2003). However, the E.coli ZntA has been reported to be specific for $\mathrm{Pb}(\mathrm{II}), \mathrm{Cd}(\mathrm{II}), \mathrm{Zn}(\mathrm{II})$, and $\mathrm{Hg}(\mathrm{II})$, but not for several other "hard" and "soft" metals including Co(II), Ni(II), and $\mathrm{Cu}$ (II) (Rensing et al. 1997, 1998; Sharma et al. 2000). In contrast, the Halobacterium NRC-1 ZntA confers resistance to $\mathrm{Co}(\mathrm{II}), \mathrm{Ni}(\mathrm{II}), \mathrm{Cu}(\mathrm{II})$, and $\mathrm{Zn}(\mathrm{II})$. Thus, we have extended the range of metal ions that can be effluxed by ZntA. There are two possible explanations for lack of correlation between metal specificity of the two $\mathrm{P}_{1}$ ATPases and the metals that affect their differential regulation, i.e., (1) an inability of underlying regulatory mechanisms to distinguish between related metal ions, or (2) adding an excess of one species of metal ions causes fluctuation in the overall intracellular metal ion pool. We discuss this further in Section 4.

\section{Section 3: Transcriptional regulation of physiological responses to metals}

\section{A preliminary wiring diagram for metal-response systems}

A systems approach uniquely enables investigation into how regulatory programs for various physiological processes are wired to each other in individual organisms to impart different phenotypes with the same systems parts (Kirschner 2005). In this context, although it is known that responses to metals are usually mediated directly by regulators that bind metal ions (metalloregulatory proteins) (O'Halloran 1993), there is little information regarding how these various regulatory systems are wired with respect to each other and other physiological processes. In Halobacterium NRC-1, of $\sim 130$ putative transcription regulators ( $\mathrm{Ng}$ et al. 2000; Bonneau et al. 2004), at least 13 are associated with metal-binding protein domains DtxR/MntR/Idr (PF02742, PF01325) (Alekshun et al. 2001) and ArsR (PF01022) (Cook et al. 1998). Seven of these were among the 48 transcription factors and regulators that were differentially regulated during the metal response (Supplemental Table 2). Furthermore, among the 13 general transcription factors (GTFs), at least four TFBs ( $t f b B, t f b G$, $t f b F$, and $t f b A)$ and one TBP $(t b p E)$ were also differentially regulated in multiple metals, which is perhaps indicative of the global nature of the metal stress response. It has been hypothesized that the regulatory circuit in Halobacterium NRC-1 might have a stratified architecture in which the multiple GTFs orchestrate global responses and the transcription regulators mediate finer control (Baliga et al. 2000). An in-depth study to evaluate this hypothesis has generated a protein-DNA interaction map for eight GTFs using the ChIP-chip method. Briefly, C-terminally c-myc epitope-tagged seven individual TFBs were formaldehyde crosslinked to their cognate DNA-binding sites in vivo in each strain expressing the respective factor. The chromatin-bound transcription complexes from each strain were selectively enriched by immunoprecipitation with c-myc-specific antibodies. The enriched DNA was sheared, released from the transcription complexes, and localized by hybridization against a halobacterial whole genome array-this yielded a protein-DNA interaction map for the GTFs (M.T. Facciotti, M. Pan, A. Kaur, M. Vuthoori, D.J. Reiss, R. Bonneau, P. Shannon, S. Donahoe, L. Hood, and N.S. Baliga, in prep.). In this network, promoters of 24 of 43 regulators that were differentially regulated during the metal re- 

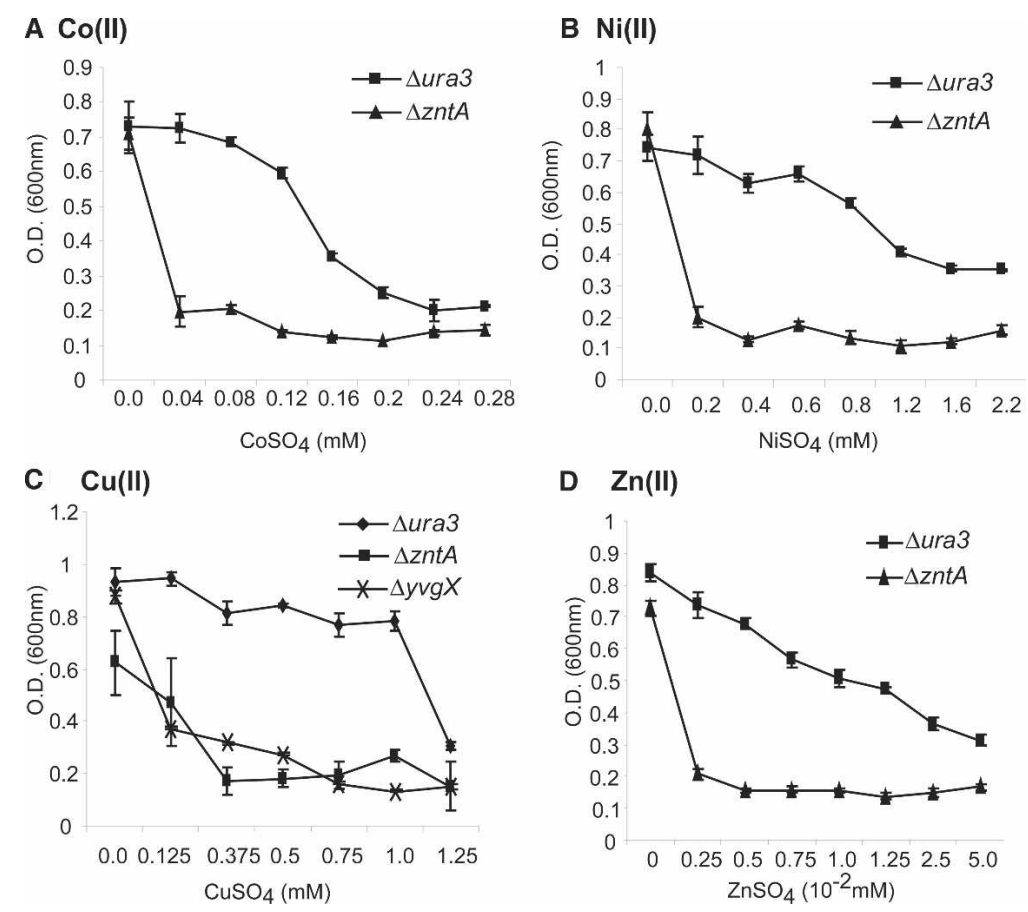

D $\mathrm{Zn}$ (II)

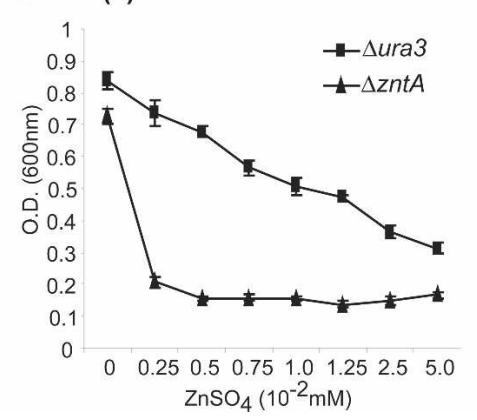

Figure 3. Two $\mathrm{P}_{1}$ ATPases are necessary for resistance to four transition metals: $\mathrm{Co}(\mathrm{II}), \mathrm{Ni}(\mathrm{II}), \mathrm{Cu}(\mathrm{II})$, and $\mathrm{Zn}(\mathrm{III})$. Growth phenotypes of $\mathrm{P}_{1}$ ATPase gene knockout strains $\Delta y v g X$ and $\Delta z n t A$ were determined as final cell density $\left(\mathrm{OD}_{600}\right)$ after $27 \mathrm{~h}$ incubation at $37^{\circ} \mathrm{C}$ in increasing concentrations of (i) $\mathrm{Co}$ (II), (ii) $\mathrm{Ni}(\mathrm{II})$, (iii) $\mathrm{Cu}(\mathrm{II})$, and (iv) Zn(II). Results from growth rate assays on these strains in different metals are presented in Supplemental Figure 3. $\Delta u r a 3$ is the parent strain in which gene deletions are constructed.

sponse had transcription-factor binding sites (TFBS) for one or more GTFs (seven TFBs and one TBP) (M.T. Facciotti, M. Pan, A. Kaur, M. Vuthoori, D.J. Reiss, R. Bonneau, P. Shannon, S. Donahoe, L. Hood, and N.S. Baliga, in prep.). Notably, transcript levels for 17 of these 24 transcription regulators changed under conditions in which the corresponding TFB mRNA level also changed (Supplemental Table 4). A plausible hypothesis is that upon sensing changes in metal concentrations, metal-binding regulators differentially regulate themselves, GTFs, and other nonmetalbinding transcription regulators. The GTFs subsequently orchestrate global coordination of the metal response.

\section{Inference and verification of key regulatory circuits}

Next, we discovered key regulatory mechanisms at play in the metal response by statistically learning a regulatory influence network for Halobacterium NRC-1 using two algorithmscMonkey (D.J. Reiss, N.S. Baliga, and R. Bonneau, in prep.), and Inferelator (Bonneau et al. 2006). Briefly, using a principle of biclustering (clustering genes and conditions) cMonkey scans the entire expanse of microarray data by iteratively evaluating membership of genes and conditions in a given bicluster. cMonkey uses a probabilistic framework to guide the biclustering procedure with functional associations and de novo motif detection. Thus, by virtue of shared cis-regulatory motifs, the biclusters identified by cMonkey often contain genes that are putatively coregulated (rather than merely coexpressed) over a subset of environmental conditions. Next, the machine-learning algorithm Inferelator uses regression and variable selection (statistical techniques for the selection of a parsimonious subset from a number of potential predictors) to identify the most likely tran- scriptional influences on each bicluster (or individual gene), based upon the integration of genome annotation (i.e., transcription factors/regulators) and expression data. Specifically, using timelagged correlation of mRNA level changes in the regulator and the average mRNA profile of a given bicluster, the Inferelator statistically assesses whether the regulator may influence transcription of genes in the bicluster. The resulting network of such inferred regulatory influences (72 transcription factors and 10 environmental factors influencing 1934 genes) includes numerical estimates of the relative strength of each regulatory influence and instances of predicted combinatorial control (Bonneau et al. 2006). We describe experimental verifications of two key regulatory relationships predicted by this procedure as follows.

\section{SirR-mediated down-regulation of Mn(II)-uptake may be a primary mechanism of controlling Mn(II) toxicity}

The first prediction was that SirR is an activator of several transporter genes including putative Mn-uptake (ZurA, ZurM, YcdH) (Supplemental Fig. 4A,B), a relationship evident in correlated changes in mRNA levels for these genes (Supplemental Fig. 6). This prediction is consistent with the putative function of SirR in that it belongs to a family of regulators implicated in transcriptional control of Mn uptake (Hantke 2001). Consistent with the Inferelator predictions, deletion of SirR increased sensitivity to Mn(II) (Fig. 4IA).

To characterize the mechanistic basis for this phenotypic trait, mRNA level changes in $\Delta$ sirR and its parent strain ( $\Delta u r a 3)$ cultured with and without three concentrations of $\mathrm{Mn}(\mathrm{II})(0.8$, 1.0 , and $1.5 \mathrm{mM}$ ) were measured with microarray analysis, normalized (mean $=0$ and variance $=1$ ) and analyzed with the SAM (Significance Analysis for Microarrays) algorithm (Supplemental Fig. 4C) (Tusher et al. 2001). Included among 90 unique changes that were identified by this procedure (Fig. 4IB; Supplemental Fig. 4) was up-regulation of the putative Mn uptake genes (zurA, $z u r M$, and $y c d H)$ in $\Delta$ sirR (Fig. 4IC). This suggested that SirRmediated transcriptional down-regulation of active uptake may be a mechanism of resistance to $\mathrm{Mn}(\mathrm{II})$, as is the case for both Bacillus subtilis and yeast (Que and Helmann 2000; Jensen et al. 2003). However, this finding is in conflict with the Inferelator prediction that SirR is an activator of zurA, zurM, and $y c d H$ (Bonneau et al. 2006). The likely explanation is that SirR is a Mn(II)dependent autorepressor. If so, then mRNA profiles for SirR would indeed be correlated with the genes it represses, i.e., zurA, $z u r M$, and $y c d H$. Indeed, other regulators of the MntR family to which SirR belongs are also Mn(II)-dependent repressors (Que and Helmann 2000).

\section{Transcriptional activation of the $P_{1}$ ATPase $Y v g X$ by VNG1179C is critical for survival under Cu(II) stress}

The second prediction was that VNG1179C, a putative Lrp family regulator with a metal-binding TRASH (trafficking, resistance, 


\section{SirR down regulates a $\mathrm{Mn}$-uptake $\mathrm{ABC}$ transport system in the presence of $\mathrm{Mn}$ (II)}

A

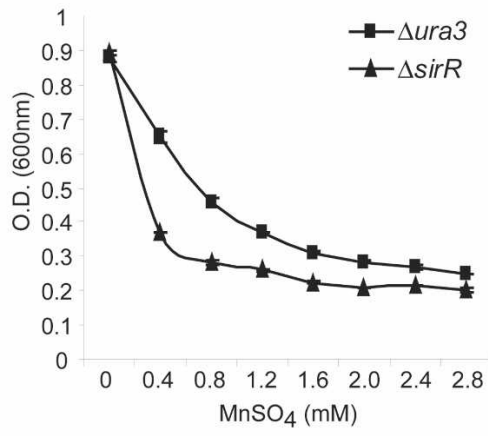

B

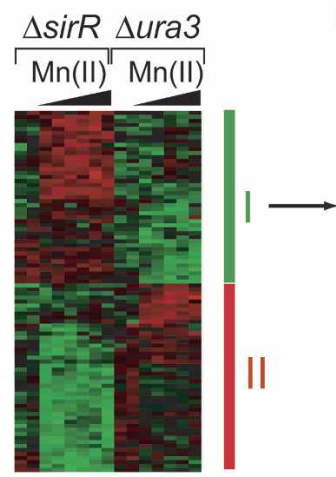

C

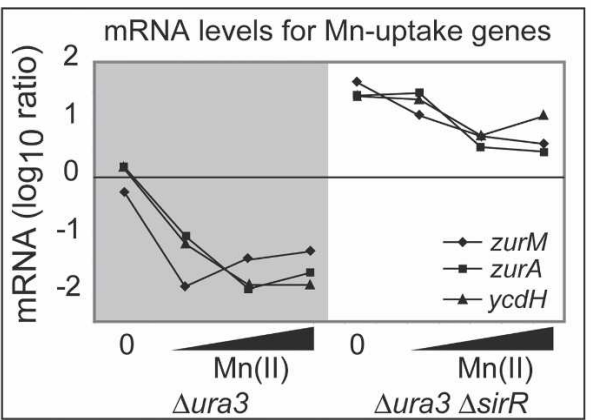

\section{VNG1179C activates a Cu(II)-efflux ATPase in a Cu(II)-dependent manner}

A

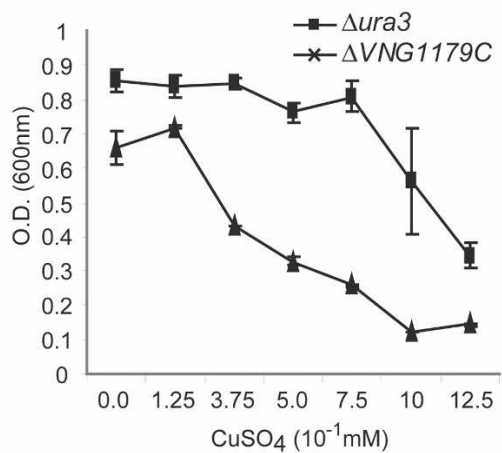

B

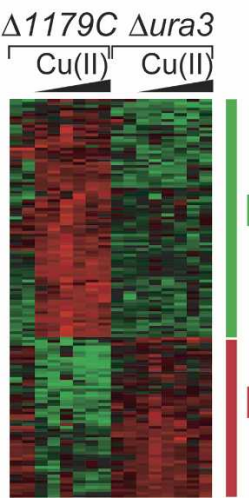

C

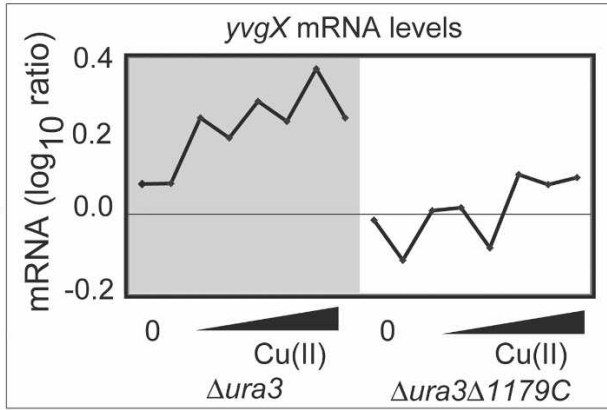

Figure 4. Transcriptional control of resistance to $\mathrm{Mn}(\mathrm{II})$ and $\mathrm{Cu}(\mathrm{II})$. (I.) SirR is a $\mathrm{Mn}$ (II)-dependent repressor of the $\mathrm{Mn}$-uptake $\mathrm{ABC}$ transport system genes-zurA, zurM, and $y c d h$. (A) Effect of $\mathrm{Mn}(\mathrm{II})$ on survival of the $\Delta$ sirR strain relative to the parent $\Delta$ ura 3 strain. Growth was measured as increase in cell density $\left(\mathrm{OD}_{600}\right)$ after culturing for $27 \mathrm{~h}$ at $37^{\circ} \mathrm{C}$ in the presence of increasing concentrations of Mn(II). (B) Ninety differences in transcriptional responses to $\mathrm{Mn}(\mathrm{II})$ in the $\Delta$ sirR strain relative to the parent $\Delta$ ura3 strain were determined using the SAM algorithm (Tusher et al. 2001) (Supplemental Fig. 6), normalized (variance $=1$; mean $=0$ ) and hierarchical clustered (Euclidean distance/Average Linkage). (C) Normalized log 10 ratios of mRNA level changes for $z u r A$, zurM, ycdH, (identified in group I in the two hierarchical clusters in $B$ in the absence and presence of Mn(II) in $\Delta$ ura 3 and $\Delta$ sirR strain backgrounds. Transcript levels for these ABC transporter subunits are down-regulated in the presence of SirR and Mn(II). (II.) VNG1179C is a Cu(II)dependent activator of the Cu(II)-efflux ATPase YvgX. (A) Effect of Cu(II) on survival of $\Delta$ VNG $1179 \mathrm{C}$ strain relative to the parent $\Delta$ ura3 strain. Survival was measured as described above, but with increasing doses of $\mathrm{Cu}(\mathrm{II})$ instead of $\mathrm{Mn}(\mathrm{II})$. (B) A total of 139 differences in transcriptional response to $\mathrm{Cu}$ (II) in the $\Delta V N G 1179 C$ strain relative to the parent $\Delta$ ura3 strain were filtered, normalized, and clustered as described in $B$ (SF2). (C) $y v g X$ was identified among genes in group II of the two main hierarchical clusters. Raw $\log _{10}$ ratios of mRNA level changes for $y v g X$ in the absence and presence of $\mathrm{Cu}(\mathrm{II})$ in the $\Delta$ ura3 and $\Delta V N G 1179 C$ strain backgrounds indicate that it is up-regulated only in the presence of both Cu(II) and VNG1179C.

and sensing of heavy metals; signature: $\mathrm{C} \times \mathrm{C} \times \mathrm{C}$ ) domain (Ettema et al. 2003; Schelert et al. 2004), is the transcriptional activator of the $\mathrm{P}_{1}$ ATPase, $y v g X$, which was required for growth with $\mathrm{Cu}(\mathrm{II})$. We first verified this prediction by demonstrating that deletion of VNG1179C significantly increased $\mathrm{Cu}$ (II) sensitivity (Fig. 4IIA). Next, using SAM as described above, we detected 139 transcriptional differences between $\Delta V N G 1179 C$ and $\Delta u r a 3$ strains (Fig. 4IIA,B; Supplemental Fig. 5) cultured with and without three concentrations of $\mathrm{Cu}(\mathrm{II})(0.7,0.85$, and $1.0 \mathrm{mM})$. This demonstrated that $y v g X$ mRNA was indeed up-regulated only in the presence of both $V N G 1179 \mathrm{C}$ and $\mathrm{Cu}(\mathrm{II})$ (Fig. 4IIC) providing further evidence that VNG1179C is a $\mathrm{Cu}(\mathrm{II})$-dependent transcriptional activator of this gene. To the best of our knowledge, this is the first in vivo verification of TRASH domain function in regulation of metal resistance. Notably, this regulatory relationship was statistically learned de novo through analysis of transcriptional responses to an array of environmental perturbations and was not reported for any organism or obvious by merely com- paring transcriptional changes in $y v g X$ and VNG1179C in $\mathrm{Cu}(\mathrm{II})$ (Supplemental Fig. 2).

Section 4: Analysis of transcriptional responses may provide clues into in vivo metal selectivity of metalloregulatory proteins

Defective metal trafficking can have detrimental physiological consequences (Andrews 2002) and, therefore, knowledge of in vivo metal selectivity is key in understanding metal homeostasis (Finney and O'Halloran 2003; Tottey et al. 2005). While kinetic and thermodynamic analyses are deemed necessary to fully understand the mechanistics of metal allocation (Finney and O'Halloran 2003), we evaluated whether comparison of transcriptional responses to different metals might provide tangible leads to decipher in vivo metal selectivity of metal-binding transcription regulators, as has been previously suggested (Tottey et al. 2005). Specifically, we conducted hierarchical clustering and 
A

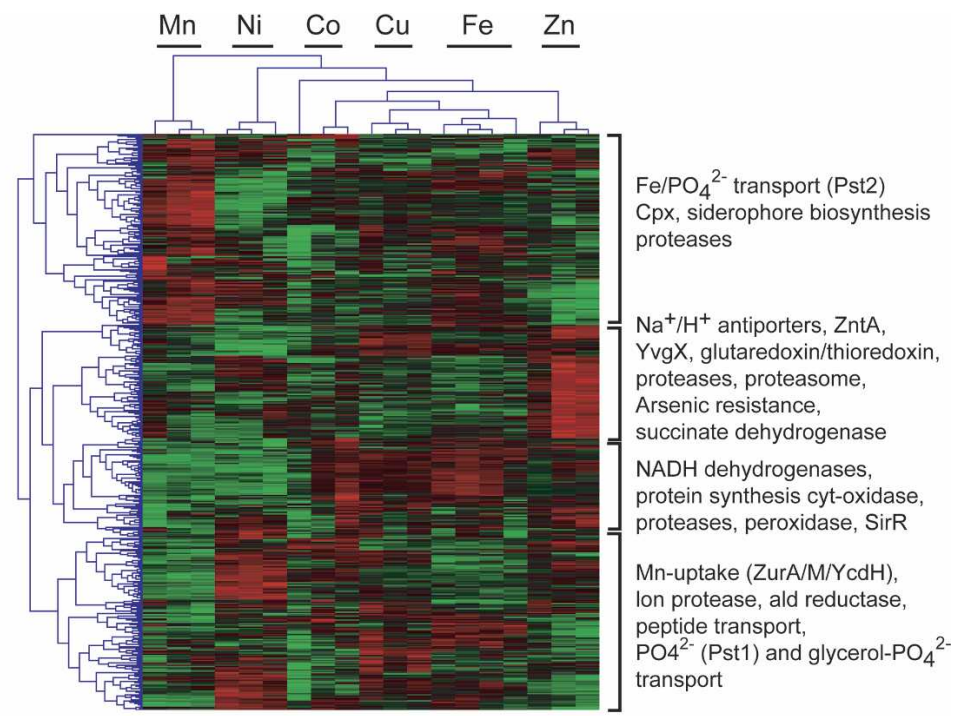

B

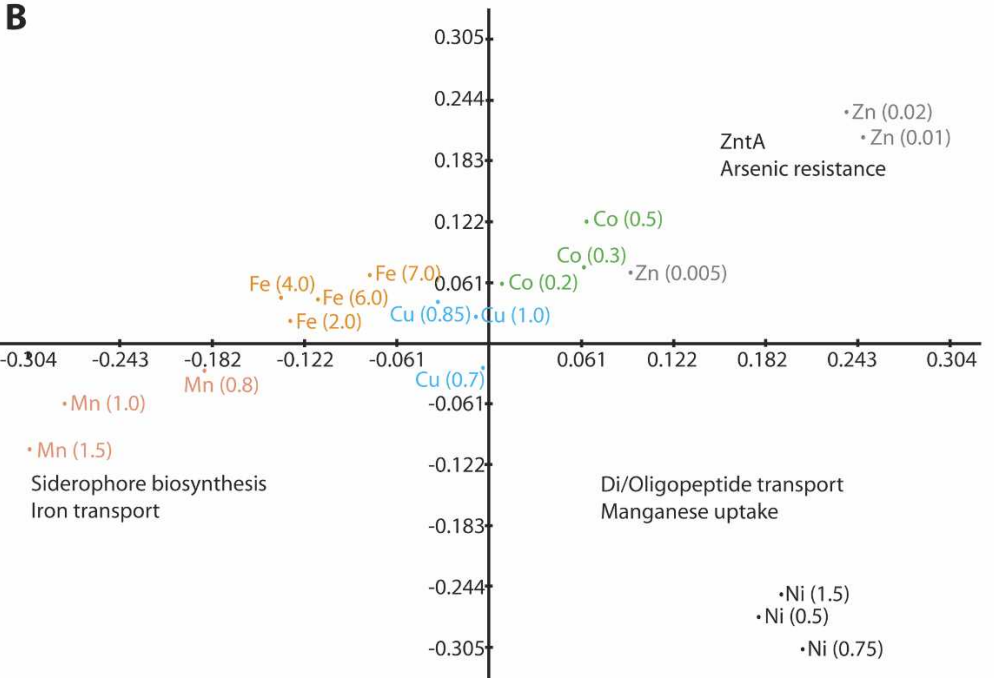

Figure 5. Correlation among responses to different transition metals. $(A)$ Hierarchical clustering on normalized mRNA $\log _{10}$ ratios for 468 genes that changed significantly $(\lambda>15)$ in at least two conditions. (B) Correspondence analysis on the same data set illustrates relatedness among both experiments as well as genes (for sake of clarity, genes are not shown; instead, relative positions of some key functions are highlighted on the plot). Each dot in this graph represents an experiment; for example, Co (0.5) refers to mRNA level changes in $0.5 \mathrm{mM} \mathrm{Co2+.} \mathrm{Eigen} \mathrm{values} \mathrm{are} \mathrm{plotted} \mathrm{for} \mathrm{each} \mathrm{of} \mathrm{the} \mathrm{first}$ two dimensions, indicated as Axes 1 and 2, which represent inertia values of 26.34 and 19.45, respectively.

correspondence analysis (CA) (Fellenberg et al. 2001) on normalized mRNA levels $($ variance $=1$, mean $=0$ ) for 447 genes that changed significantly $(\lambda>15)$ in at least two of the 19 conditions (different concentrations of the six metals) during metal response (Fig. 5). Briefly, CA calculates associations among variables and projects these associations in a two-dimensional space similar to principle component analysis (PCA). Unlike PCA, CA can project associations among genes and among experimental conditions onto the same two-dimensional space. This enables discovery of relationships among experiments, among genes, and also across genes and experiments.

From these analyses we learned that responses at higher concentrations of some metals appeared similar to those induced by other metals. For example, there was considerable similarity between responses to $\mathrm{Co}(\mathrm{II}), \mathrm{Zn}(\mathrm{II})$, and $\mathrm{Ni}$ (II) (Figs. 5B, 6A;
Supplemental Fig. 7A,B,C). Likewise, transcriptional responses to $\mathrm{Fe}(\mathrm{II})$ bore similarity to $\mathrm{Cu}(\mathrm{II})$-induced responses (Supplemental Fig. 7A). This high degree of similarity in global responses to these metals is indicative of similar function, binding preferences, and coordination geometries of those metals or a possible breakdown in metal trafficking systems under increased metal stress (Lin et al. 1997). Further, the global response analysis provided further insight into key associations among physiologic functions and metals that elicited maximal change in their transcription. For example, ZntA and arsenic-resistance genes are strongly associated with $\mathrm{Zn}$ (II) responses. The likely regulatormediating response of the arsenic resistance genes is VNG5176C (ArsR2) of the ArsR/SmtB family of regulators, which contain the $\alpha 3 \mathrm{~N}$ metal-binding site that can functionally bind $\mathrm{Zn}$ (II) ions (Cavet et al. 2002). In Halobacterium NRC-1, the arsenic-resistance genes are also induced by the cognate metal (As) (Wang et al. 2004) suggesting that perhaps ArsR 2 can functionally bind both As and Zn. We will discuss three specific cases wherein using transcriptional responses as a proxy, we suggest putative in vivo metal selectivity of transcription regulators.

\section{Mn(II) may cause iron starvation-like conditions in Halobacterium NRC-1}

Putative Fe uptake (Ibp, HemV2, YfmF, and FepC) and siderophore biosynthesis genes were down-regulated by $\mathrm{Ni}$ (II) and $\mathrm{Zn}$ (II) and up-regulated by $\mathrm{Mn}$ (II) (Fig. $6 \mathrm{~B})$, suggesting a fairly complex interplay among these transition metals in control of Fe metabolism. Mn(II)induced up-regulation of these genes suggests that $\mathrm{Mn}$ (II) mimics an Fe(II)starvation condition in Halobacterium NRC-1. This hypothesis was confirmed upon observing moderate up-regulation of these genes at lower concentrations of 2, 2'-dipyridyl (DIP)—a metal chelator (Fig. 6B). Transcript levels for these genes dropped at a higher DIP concentration $(0.25 \mathrm{mM})$, which also caused complete growth inhibition, perhaps due to complete lack of "free" Fe ions (Fig. 6C). However, the inability of DIP to completely derepress (or activate) siderophore biosynthesis genes and Fe uptake genes as has been demonstrated for B. subtilis (Baichoo et al. 2002) suggests that we might have not achieved sufficient Fe starvation levels. If so, then DIP might also be chelating some other divalent ion(s), such as Zn(II) (Patzer and Hantke 1998), which are in limited supply in the growth medium for Halobacterium NRC-1.

In aqueous solutions, the ionic radius of $\mathrm{Mn}(\mathrm{II})(0 \cdot 80 \AA)$ is intermediate to that of $\mathrm{Mg}(\mathrm{II})(0.65 \AA)$ and $\mathrm{Ca}(\mathrm{II})(0.99 \AA)$, and close to that of $\mathrm{Fe}(\mathrm{II})(0 \cdot 76 \AA)$. Consequently, $\mathrm{Mn}(\mathrm{II})$ and other 
A. Active lon transport mRNAs

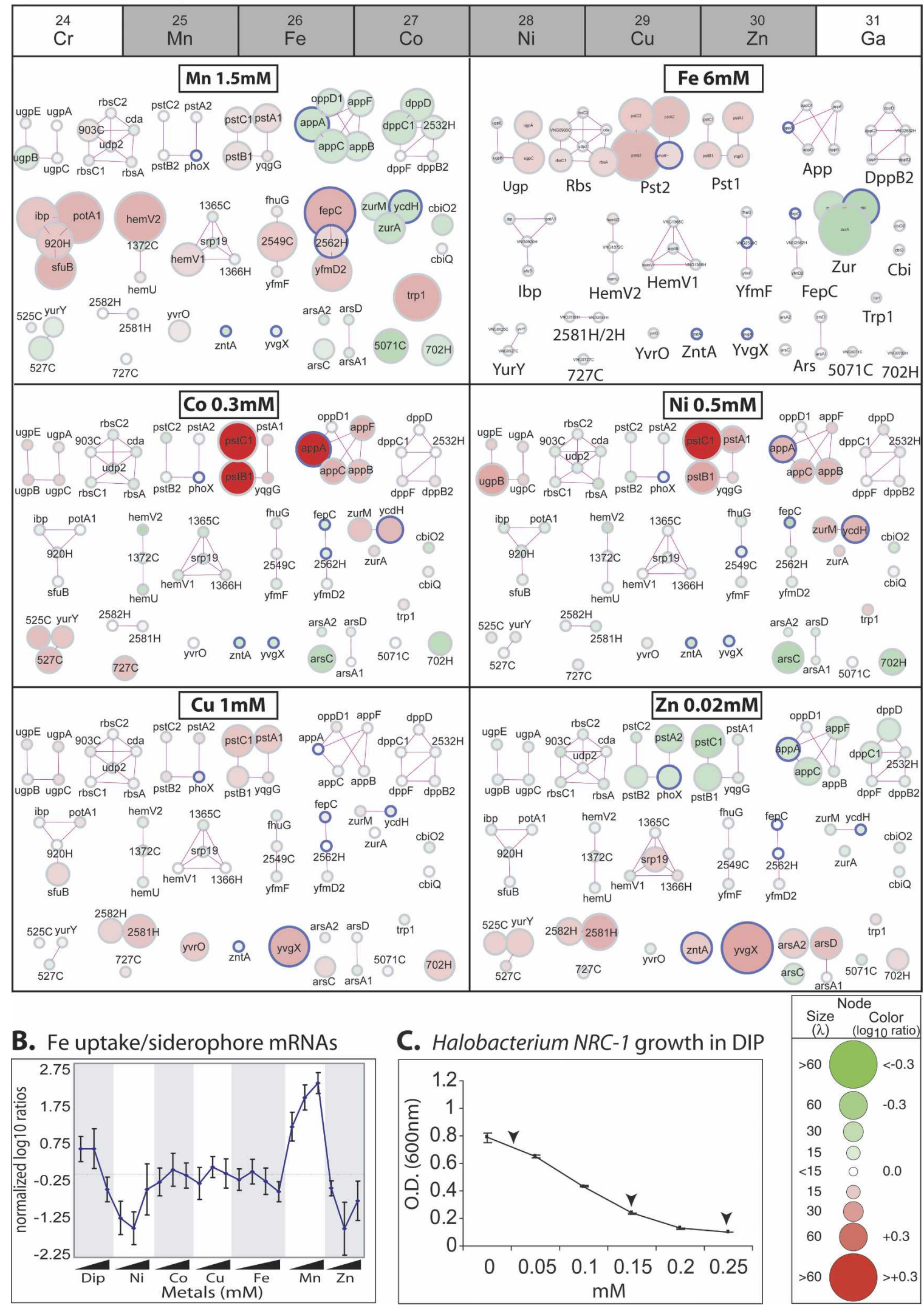

Figure 6. (Legend on next page) 
cations are interchangeable in metal-binding sites of many proteins (Jakubovics and Jenkinson 2001). In fact, a high concentration of $\mathrm{Mn}$ (II) appears to displace Fe(II) from cellular-binding sites in B. subtilis; the resulting transient increase in "free" Fe(II) is sensed by the ferric uptake regulator (Fur), causing lethal repression of siderophore biosynthesis and Fe uptake systems (Guedon et al. 2003). In contrast, the Mn(II)-induced Fe-deficiency in Halobacterium NRC-1, which lacks a Fur ortholog, suggests that the function of an unidentified Fe homeostasis regulator in this archaeon is inhibited upon binding $\mathrm{Mn}(\mathrm{II})$.

\section{VNG1179C may function as an activator with either Cu(II) or $\mathrm{Zn}(I I)$ cofactors bound to the TRASH domain}

The Cu(II)-efflux ATPase YvgX was transcriptionally up-regulated by both $\mathrm{Cu}$ (II) and $\mathrm{Zn}$ (II). This suggests that the TRASH domain in $V N G 1179 C$, the putative regulator of $y v g X$, can function normally upon binding either $\mathrm{Cu}(\mathrm{II})$ or $\mathrm{Zn}(\mathrm{II})$. Interestingly, the putative $\mathrm{Cu}$ (II) trafficking chaperones (COG2608) (VNG0702H and VNG2581H) in Halobacteruim NRC-1 were both significantly upregulated in $\mathrm{Cu}(\mathrm{II})$ and $\mathrm{Zn}(\mathrm{II})$ (Fig. 6A; Supplemental Table 2).

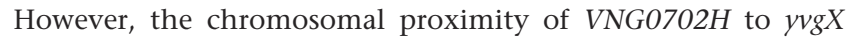
coupled to its unresponsiveness to $\mathrm{Cu}(\mathrm{II})$ in the $\Delta V N G 1179 \mathrm{C}$ strain (Supplemental Fig. 5) makes it the likely $\mathrm{Cu}(\mathrm{II})$ chaperone for YvgX. Our hypothesis is that one or both of these two putative $\mathrm{Cu}(\mathrm{II})$ chaperones is constitutively present in the cell at a basal level, trafficking $\mathrm{Cu}$ (II) ions to appropriate ligands. Under increased $\mathrm{Cu}$ (II) and $\mathrm{Zn}$ (II) stress, these ions are chaperoned to the TRASH domain of VNG1179C, which in turn activates transcription of the putative $\mathrm{Cu}(\mathrm{II})$ chaperone(s) (VNG0702H/ VNG2581H) and the Cu(II) efflux ATPase (YvgX).

In the model above, the metal-binding domain functions as a $\mathrm{Cu}$ (II) sensor to modulate activity of VNG1179C. This is functionally similar to modulation of activity of the human $\mathrm{Cu}(\mathrm{II})-$ translocating ATPase ATP7B by its N-terminal metal-binding HMA domains (Forbes et al. 1999), which receive $\mathrm{Cu}(\mathrm{II})$ ions from ATOX1, a metallochaperone of the COG2608 family (Hung et al. 1998; Hamza et al. 1999; Larin et al. 1999). Disruption of $\mathrm{Cu}$ (II) delivery by ATOX1 to ATP7B results in $\mathrm{Cu}$ (II) accumulation leading to Wilson's disease (Hamza et al. 1999). An important question that remains to be addressed is whether the six metal-binding domains of ATP7B differ in their in vivo metal specificity and/or affinity for $\mathrm{Cu}(\mathrm{II})$. Attempts to investigate this with fusions of ATP7B metal-binding domain with ZntA in E. coli have been unsuccessful, perhaps attributable to absence of the cognate chaperone (Jordan et al. 2001). Knowledge of mechanistics of metal trafficking by these metallochaperones to cognate metal-binding domains of diverse proteins has implications to diseases ranging from Wilson's and Menkes' disease to Alzheimer's disease (Strausak et al. 2001). In this regard, it is appealing to utilize the VNG0702H/VNG2581H//VNG1179C/YvgX system for characterizing in vivo metal selectivity of metal-binding do- mains. This is a particularly attractive model system, because changes in functions of VNG1179C can be monitored by evaluating transcriptional responses of $y v g X$, which in turn are manifested as differential survival of Halobacterium NRC-1 in $\mathrm{Cu}(\mathrm{II})$.

\section{The systemic view of a cellular response afforded by a systems approach may enable distinction of direct from indirect metal-induced changes to better understand in vivo metal-protein speciation}

As mentioned earlier, metal-induced transcriptional responses contain a mix of changes mediated by transcription factors that directly bind metal ions or by those that sense an indirect effect such as increased oxidative stress or an altered intracellular metal ion pool. This is exemplified by $\mathrm{Cu}(\mathrm{II})$-induced transcriptional changes in the $\Delta V N G 1179 C$ background, which included a large number of oxidative stress-response genes (17 dehydrogenases and seven protein and DNA damage repair genes) (Supplemental Fig. 5). By comparing global mRNA level changes across responses to all metals in wild-type and gene-deletion strains along with phenotypic assays on the $\Delta V N G 1179 C$ and $\Delta y v g X$ strains, we were able to verify the Inferelator prediction that VNG1179C putatively imposes direct control on YvgX transcription. Therefore, we predict that the overrepresentation of oxidative stressresponse genes might represent an indirect consequence of increased intracellular $\mathrm{Cu}(\mathrm{II})$ levels in absence of YvgX. This ability to unscramble direct from potentially indirect changes becomes crucial while attempting to decipher metal-binding specificity of a metalloregulator on the basis of the transcriptional responses it elicits. We have demonstrated that a systems approach may indeed prove valuable in providing insights that serve as tangible leads for further experimental inquiry into in vivo metal-protein speciation; for example, we can now predict that measuring protein-DNA interactions of VNG1179C in the presence or absence of either $\mathrm{Cu}$ (II) or $\mathrm{Zn}$ (II) is likely to provide the most biologically relevant physical evidence of this control mechanism.

\section{Section 5: A systems-level model for the complex response of Halobacterium NRC-1 to transition metals}

We have put together all findings from this study in the context of each other into one unified model of Halobacterium NRC-1 response to transition metals. According to this systems-level model, at the highest level, all or some of at least 13 putative metal-binding regulators are speculated to directly sense changes in metal ion concentrations to differentially regulate up to 43 transcription regulators and five GTFs. Promoters of at least 24 of the 43 regulators (four of which have putative metal-binding domains) have binding sites in their promoter for at least four GTFs. The remaining six metal-binding regulators are not differentially regulated (at least at steady state) in response to the six metals. The complex interplay among these transcription factors and regulators elicits a concerted response to minimize metal

\footnotetext{
Figure 6. Responses of active transport and siderophore biosynthesis genes to the six metals and 2,2' dipyridyl (DIP). ( $A$ ) mRNA level changes in key transporters and genes in their putative operons. The genes are individually labeled at top, left and at top, right; transport systems are labeled as follows: Ugp: glycerol phosphate transport; Rbs: ribose transport; Pst1 and Pst2: PO $_{4}{ }^{2-}$ transport; App and DppB2: peptide transport; Ibp, HemV2, HemV1, YfmC and FepC: Fe transport; Zur: Mn uptake; Cbi: Co uptake; YurY and YvrO: $\mathrm{ABC}$ transporters of unknown specificity; 2581H and 702H: putative Cu chaperones, (Ars) As resistance; 5071C: sugar transporter. Circular nodes represent genes of putative transport systems (Supplemental Table 2). Node coloring (red for up and green for down) indicates mRNA level change at $300 \mathrm{~min}$ in $1.5 \mathrm{mM} \mathrm{Mn}$ (II), $6 \mathrm{mM}$ Fe(II), $0.3 \mathrm{mM} \mathrm{Co}(\mathrm{II}), 0.5 \mathrm{mM} \mathrm{Ni}(\mathrm{II}), 1 \mathrm{mM}$ $\mathrm{Cu}(\mathrm{II})$, and $0.02 \mathrm{mM} \mathrm{Zn(II)-organized} \mathrm{in} \mathrm{order} \mathrm{of} \mathrm{their} \mathrm{position} \mathrm{in} \mathrm{the} \mathrm{periodic} \mathrm{table} \mathrm{(top).} \mathrm{Node} \mathrm{size} \mathrm{is} \mathrm{proportional} \mathrm{to} \lambda$ value, a measure of the statistical significance of change (see inset key). Edges (lines) connecting the nodes indicate operon-like organization. (B) mRNA level changes in 12 putative siderophore biosynthesis and Fe-uptake genes in DIP and all six metals. (C) Halobacterium NRC-1 growth (OD 600 ) at 27 h in increasing concentrations of the Fe-specific chelator DIP. Arrowheads indicate concentrations used for microarray analysis.
} 
toxicity and oxidative stress, repair damaged proteins and DNA, and modulate cell physiology including processes requiring metalloenzymes. Feedback signals including damaging radicals produced during natural cellular metabolism, fluctuations in metabolite concentrations, etc., ensure homeostasis (Fig. 7A).

We hypothesize that at least four mechanisms play central roles in conferring resistance to the six transition metals (Fig. 7B). We elaborate on these mechanisms below:

1. Cu(II) resistance: VNG0702H and/or VNG2581H are speculated to be the putative metallochaperones that deliver either $\mathrm{Cu}(\mathrm{II})$ or $\mathrm{Zn}$ (II) ions to the TRASH domain in VNG1179C, which in turn activates transcription of both YvgX (Fig. 4II) and the chaperone(s) (Fig. 6). Efflux of $\mathrm{Cu}$ (II) by the $\mathrm{P}_{1}$ ATPase $\mathrm{YvgX}$ is a key mechanism for withstanding $\mathrm{Cu}(\mathrm{II})$ toxicity; however, it does not contribute toward $\mathrm{Zn}$ (II) resistance (Supplemental Table 3).

2. $\mathrm{Co}(\mathrm{II}), \mathrm{Ni}(\mathrm{II}), \mathrm{Cu}(\mathrm{II})$, and $\mathrm{Zn}(\mathrm{II})$ resistance: $\mathrm{ZntA}$ is a $\mathrm{P}_{1}$ ATPase of broad specificity that confers resistance to $\mathrm{Co}(\mathrm{II}), \mathrm{Ni}(\mathrm{II})$, $\mathrm{Cu}$ (II), and $\mathrm{Zn}$ (II) (Fig. 3). ZntA mRNA is up-regulated at steady state only in the presence of $\mathrm{Zn}$ (II) (Fig. 6A; Supplemental Table 2); however, the regulator(s) involved is unknown.

3. Mn(II) resistance: Transcriptional repression of ZurA, ZurM, and YcdH, the three subunits of the Mn-uptake ABCtransporter, by the putative Mn-dependent autorepressor SirR is a mechanism of minimizing Mn(II) toxicity (Fig. 4I). SirR may also impose this regulation upon binding Fe(II), but its function might be blocked upon binding $\mathrm{Co}(\mathrm{II})$ or $\mathrm{Ni}$ (II) (Fig. 6A; Supplemental Table 2). However, this transcriptional control seems to only have impact on conferring resistance to Mn(II) and none of the other metals (Supplemental Table 3).

4. Fe(II) resistance: Chelation of Fe(II) by the ferritin DpsA is a mechanism for detoxifying Fe(II) (Zeth et al. 2004). Transcription of DpsA is up-regulated by Fe(II) (Reindel et al. 2005), $\mathrm{Co}(\mathrm{II})$, and $\mathrm{Zn}$ (II) and down-regulated by $\mathrm{Mn}$ (II) and Fedeficiency conditions (Reindel et al. 2005) (Supplemental Table 2); again the transcription regulator(s) for this mechanism have not been identified. Further, Mn(II) up-regulates and $\mathrm{Ni}(\mathrm{II}) / \mathrm{Zn}$ (II) down-regulates putative siderophore biosynthesis and Fe uptake (Fig. 6B; Supplemental materials).

\section{Section 6: Conclusions}

We have demonstrated that the ability of organisms to differentiate among closely related metal ions to elicit both generalized and tailored responses can be fully appreciated by a systems-level
A

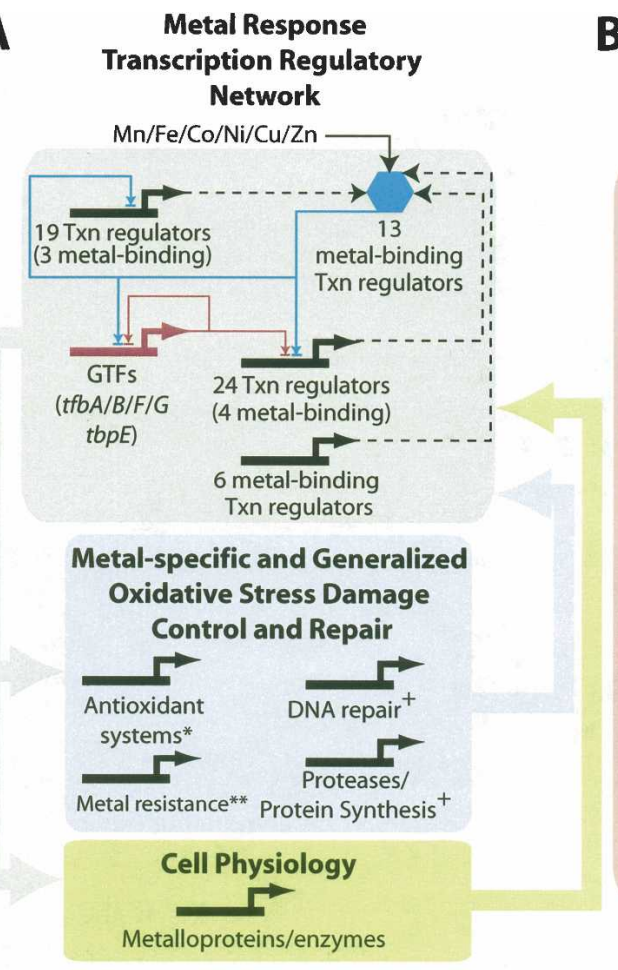

*Glutaredoxin/Thioredoxin/Detoxifying Dehydrogenase/ peroxidase/Superoxide dismutase etc.

**Efflux ATPase/ABC transporter/lon scavenging/metal reductases etc. ${ }^{+}$ +See supplementary table ST2 for genes

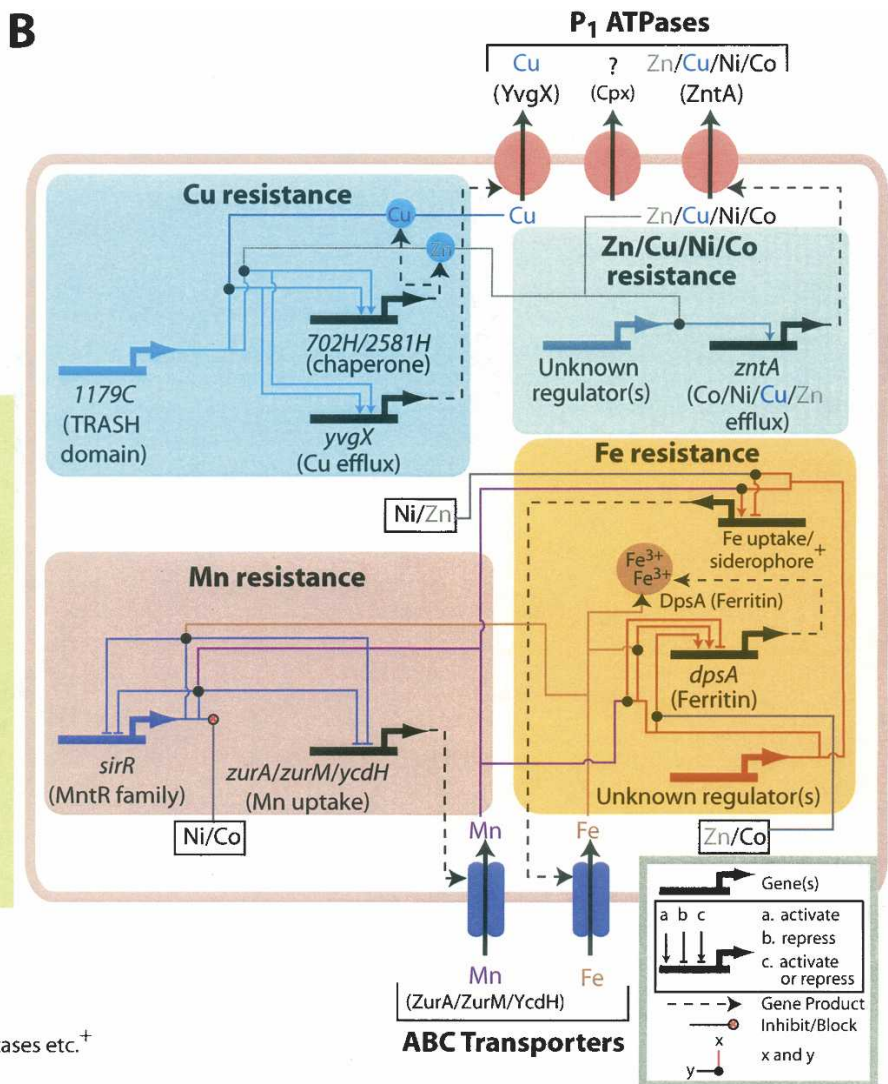

Figure 7. A systems-level model for transition metal stress response of Halobacterium NRC-1 (see text for details). (A) Transcription regulatory control of metal detoxification, oxidative stress, and general physiology in response to transitions metals. While most of the regulatory influences indicated were deciphered on the basis of mRNA level changes and putative functions, the regulatory control imposed by the GTFs were experimentally measured with ChIP-chip (M.T. Facciotti, M. Pan, A. Kaur, M. Vuthoori, D.J. Reiss, R. Bonneau, P. Shannon, S. Donahoe, L. Hood, and N.S. Baliga, in prep.). The blue and green watermark arrows indicate feedback signals. $(B)$ Key functional and regulatory aspects of metal-resistance mechanisms. Regulatory control mediated by VNG1179C and SirR was verified by both microarray analysis as well as phenotypic assays on in-frame gene-deletion strains. Likewise, efflux of metal ions by $\mathrm{YvgX}$ and ZntA was also verified through phenotypic assays on gene deletion strains. Up-regulation of siderophore biosynthesis genes by $\mathrm{Mn}(\mathrm{II})$ was verified to be due to simulation of Fe-deficiency (see text). Finally, the role of the ferritin DpsA in Fe resistance and some aspects of regulation have been previously characterized (Reindel et al. 2002, 2005; Zeth et al. 2004). See inset key for interpreting the circuit. 
study. More importantly, prior to this study there was cursory knowledge of metal physiology in Halobacterium NRC-1, or for that matter, in any archaeal organism. The systems analysis comprising 66 microarray experiments, phenotypic analyses of 17 gene deletion strains, and simultaneous analysis with diverse orthogonal sources of information enabled rapid synthesis of a systems scale model (Fig. 7) of how this organism responds to six transition metals. As expected, we discovered previously known mechanisms including efflux of metal ions by $\mathrm{P}_{1}$ ATPases, downregulation of $\mathrm{Mn}(\mathrm{II})$ uptake, ion scavenging, increased protein turnover, and minimizing ROS production; however, it is noteworthy to mention that these are all new insights for archaea. We also made several completely novel discoveries including in vivo evidence for control of transcriptional regulation by a TRASH domain, ability of Halobacterium NRC-1 ZntA to confer resistance to $\mathrm{Co}(\mathrm{II}), \mathrm{Ni}(\mathrm{II})$, and $\mathrm{Cu}(\mathrm{II})$, similarities between global responses to several metals, a putative global control mechanism mediated by GTFs and key metalloregulatory proteins, and simulation of Fe deficiency by $\mathrm{Mn}(\mathrm{II})$. Notably, the systems approach has illustrated how these varied metal responses operate in the context of each other in a single organism. It is the properties of these various processes and how they work together that ultimately describes unique phenotypes of individual organisms (Kirschner 2005). As more studies of this scope are conducted, we will be able to compare across cellular responses to diverse stress agents and tease out aspects of responses that are shared and those that are unique. In this regard, it is important to recognize that interactions among varied environmental factors may alter the nature of the response; for example, some metals such as Fe(II) are readily oxidized by oxygen to the less toxic Fe(III) state or interact with ion chelators such as citrate (which is in abundance in the halobacterial growth medium), thereby perturbing the ionic composition of the intra- and extracellular milieu. Analyses of combinatorial changes in two such interacting environmental factors is necessary to eventually enable better correlation of input (environmental perturbation) to output (phenotype or cell behavior), i.e., formulate accurate models of cell behavior in perturbed environments. Finally, this study demonstrates how a systems approach can enable rapid reconstruction of physiological responses and regulatory programs for the vast expanse of organisms with fully sequenced genomes, but little understanding from classical studies.

\section{Methods}

\section{Culturing for phenotypic assays}

\section{Survival curves of NRC-1 and mutants in transition metals}

Halobacterium NRC-1 is a wild-type strain. Growth curves in different concentrations of metals $\left[\mathrm{MnSO}_{4} \cdot \mathrm{H}_{2} \mathrm{O}(0.8-2 \mathrm{mM})\right.$, $\mathrm{FeSO}_{4} \cdot 7 \mathrm{H}_{2} \mathrm{O}(5-10 \mathrm{mM}), \mathrm{CoSO}_{4} \cdot 7 \mathrm{H}_{2} \mathrm{O}(0.1-0.9 \mathrm{mM}) \mathrm{NiSO}_{4} \cdot 6 \mathrm{H}_{2} \mathrm{O}$ (0.25-2.5 mM), $\mathrm{CuSO}_{4} \cdot 5 \mathrm{H}_{2} \mathrm{O}(0.7-1.2 \mathrm{mM}), \mathrm{ZnSO}_{4} \cdot 7 \mathrm{H}_{2} \mathrm{O}(0.01-$ $0.05 \mathrm{mM}$ ) (Sigma), and Fe chelator 2,2'-Dipyridyl (0.005-0.2 $\mathrm{mM})$ ] (Acros Organics) were conducted in complex growth medium (CM: NaC-250g/L, $\mathrm{MgSO}_{4} \cdot 7 \mathrm{H}_{2} \mathrm{O}-20 \mathrm{~g} / \mathrm{L}, \mathrm{Na} \cdot \mathrm{Citrate}-3 \mathrm{~g} / \mathrm{L}$, $\mathrm{KCl}-2 \mathrm{~g} / \mathrm{L}$, and peptone $10 \mathrm{~g} / \mathrm{L}$ ) with a starting $\mathrm{OD}_{600}$ at 0.05 . Cultures were incubated at $37^{\circ} \mathrm{C}$ and $220 \mathrm{rpm}$ shaking and overall change in cell density was used as a measure of growth (Fig. 1). Survival assays for gene knockout strains were also conducted in CM growth medium with uracil in 14-mL falcon tubes or 96-well format Beckman culture plates. Each growth and survival experiment was conducted at least twice with at least three independent replicates each time.

\section{Survival assays on CM plates}

A total of $4 \mathrm{~mL}$ of a mid-log culture of Halobacterium NRC-1 (OD $\sim 0.5-0.6$ ) were aliquoted into falcon tubes ( $4 \mathrm{~mL}$ each) and cells were harvested at $30 \mathrm{~min}, 1 \mathrm{~h}, 3 \mathrm{~h}, 6 \mathrm{~h}$, and $27 \mathrm{~h}$ after addition of metal salts $\left[\mathrm{MnSO}_{4}(2 \mathrm{mM}), \mathrm{FeSO}_{4}(9.8 \mathrm{mM}), \mathrm{CoSO}_{4}(0.5 \mathrm{mM})\right.$ $\left.\mathrm{NiSO}_{4}(2.5 \mathrm{mM}), \mathrm{CuSO}_{4}(1.25 \mathrm{mM}), \mathrm{ZnSO}_{4}(0.05 \mathrm{mM})\right]$, and spotted on to $\mathrm{CM}$ agar plates $\left(5 \mu \mathrm{L}\right.$ of $10^{-4}, 10^{-5}, 10^{-6}$, and $10^{-7}$ dilution). Colonies were counted after $5-6 \mathrm{~d}$ incubation at $37^{\circ} \mathrm{C}$.

\section{Culturing for RNA preparation}

\section{Steady-state analysis}

Mid-log phase $\left(\mathrm{OD}_{600}=\sim 0.5-0.6\right)$ Halobacterium $N R C$ - 1 cultures were exposed for $5 \mathrm{~h}$ to different concentrations of metals (Fig. 1) $\left(\mathrm{MnSO}_{4}: 0.8,1\right.$, and $1.5 \mathrm{mM} ; \mathrm{FeSO}_{4}: 2,4,6$, and $7 \mathrm{mM}$; $\mathrm{CoSO}_{4}$ : $0.2,0.3$, and $0.5 \mathrm{mM} ; \mathrm{NiSO}_{4}: 0.5,0.75$, and $1.5 \mathrm{mM} ; \mathrm{CuSO}_{4}: 0.7$, 0.85 , and $1 \mathrm{mM} ; \mathrm{ZnSO}_{4}: 0.005,0.010$, and $0.020 \mathrm{mM}$ ) and DIP: (Fig. 2B) $0.025,0.1$ and $0.25 \mathrm{mM}$.

\section{Time Series analysis for evaluating response to $6 \mathrm{mM} \mathrm{FeSO}_{4}$}

Halobacterium NRC-1 cells were cultured in $1.5 \mathrm{~L}$ of $\mathrm{CM}$ in batch format using the BioFlo100 modular bench-top fermentor (New Brunswick Scientific). The following parameters were maintained during culturing $\mathrm{pH}$ : 7.0 (maintained by pumping in $0.5 \mathrm{~N}$ $\mathrm{H}_{2} \mathrm{SO}_{4}$ or $\left.0.5 \mathrm{~N} \mathrm{NaOH}\right), \mathrm{d}\left[\mathrm{O}_{2}\right]: 100 \%$ and agitation: $300 \mathrm{rpm}$. Percent air saturation in the medium was monitored with an $\mathrm{O}_{2}$ sensor (InPro 6000, Mettler Toledo) calibrated to 100\% oxygen by sparging $3.2 \mathrm{VVM}$ (vessel volume per minute) rotameter air flowrate and $1200 \mathrm{rpm}$ agitation prior to culture inoculation. At mid $\log$ phase $\left(\mathrm{OD}_{600} \sim 0.65\right)$, the culturing was shifted to continuous mode and cell density was maintained by diluting the culture with fresh medium; spent medium was pumped out at the same rate to maintain culture volume at $1.5 \mathrm{~L}$. On the third day, $\mathrm{FeSO}_{4}$ was added to the continuous culture to a final concentration of $6 \mathrm{mM}$. Then, 5-6-mL culture aliquots were collected using the following sampling schedule: 11 time points (1 min before adding $\mathrm{FeSO}_{4}$, and a subsequent time course of 10 points: $0,5,10,15,20,25,40,80,160$, and $320 \mathrm{~min})$. Each sample was immediately centrifuged and the cell pellets were flash frozen in a dry ice/ethanol bath to minimize both unintended perturbations and change in transcriptome state.

\section{RNA preparation}

Total DNA-free RNA was prepared using the Absolutely RNA miniprep kit (Strategene) and analyzed by PCR to rule out DNA contamination, with Agilent Bioanalyzer to verify integrity, and in the spectrophotometer for quantification.

\section{Construction of in-frame gene deletion strains}

An in-frame deletion copy of all but the first 21 bp of each gene was constructed in vitro by fusing with recombinant PCR two overlapping 500-bp PCR fragments from upstream and downstream segments of each gene. The intact chromosomal copy was replaced in a two-step process with the deletion copy. First crossover recombinants were selected for mevinolin resistance. Second cross-over recombinants were subsequently enriched by selecting for 5-FOA resistance due to loss of the intact ura3 gene copy on the plasmid. The $5-\mathrm{FOA}^{\mathrm{r}}$ isolates were screened by PCR for gene deletion (Supplemental Tables 5, 6).

\section{Microarray analysis}

Microarray slide fabrication, RNA preparation, labeling with Alexa547 and Alexa647 dyes (Molecular Probes and Kreatech BV), 
hybridization, and washing were conducted as described previously (Baliga et al. 2004). Raw spot intensity values for each gene (eight replicate spots from two slides including dye-flip) were median normalized and evaluated for statistical significance of differential expression by maximum likelihood analysis with VERA and SAM algorithms (Ideker et al. 2000). Comparison of RNA from biological replicates using this procedure consistently yields low $\lambda$ values $<15$ for over $99 \%$ of all genes. Changes associated with $\lambda$ values $>15$ are therefore considered statistically significant in our experiments-usually representing a false positive rate of $<1 \%$. All steady-state experiments were conducted with at least two biological replicates. Data from the microarray processing pipeline were archived using the DataLoader (M.H. Johnson, D. Tenenbaum, P. Shannon, and N.S. Baliga, in prep.) with all associated experimental design and sample processing parameters.

\section{Acknowledgments}

We thank Rich Bonneau, Amy Schmid, Kenia Whitehead, Isabel Materon, and Leroy Hood for critical reading of the manuscript. We are also grateful to John D. Helmann for his insightful comments. This work was funded through grants from NSF (EIA0220153; MCB-0425825; EF-0313754) and DoE (DAAD13-03-O0057) to N.S.B.

\section{References}

Alekshun, M.N., Levy, S.B., Mealy, T.R., Seaton, B.A., and Head, J.F. 2001. The crystal structure of MarR, a regulator of multiple antibiotic resistance, at $2.3 \AA$ resolution. Nat. Struct. Biol. 8: 710-714.

Andrews, N.C. 2002. Metal transporters and disease. Curr. Opin. Chem. Biol. 6: 181-186.

Babich, H. and Stotzky, G. 1980. Environmental factors that influence the toxicity of heavy metal and gaseous pollutants to microorganisms. Crit. Rev. Microbiol. 8: 99-145.

Baichoo, N., Wang, T., Ye, R., and Helmann, J.D. 2002. Global analysis of the Bacillus subtilis Fur regulon and the iron starvation stimulon. Mol. Microbiol. 45: 1613-1629.

Baliga, N.S., Goo, Y.A., Ng, W.V., Hood, L., Daniels, C.J., and DasSarma, S. 2000. Is gene expression in Halobacterium NRC-1 regulated by multiple TBP and TFB transcription factors? Mol. Microbiol. 36: 1184-1185.

Baliga, N.S., Pan, M., Goo, Y.A., Yi, E.C., Goodlett, D.R., Dimitrov, K., Shannon, P., Aebersold, R., Ng, W.V., and Hood, L. 2002. Coordinate regulation of energy transduction modules in Halobacterium sp. analyzed by a global systems approach. Proc. Natl. Acad. Sci. 99: 14913-14918.

Baliga, N.S., Bjork, S.J., Bonneau, R., Pan, M., Iloanusi, C., Kottemann, M.C.H., Hood, L., and DiRuggiero, J. 2004. Systems level insights into the stress response to UV radiation in the halophilic archaeon Halobacterium NRC-1. Genome Res. 14: 1025-1035.

Bateman, A., Birney, E., Durbin, R., Eddy, S.R., Howe, K.L., and Sonnhammer, E.L. 2000. The Pfam protein families database. Nucleic Acids Res. 28: 263-266.

Blindauer, C.A., Harrison, M.D., Robinson, A.K., Parkinson, J.A., Bowness, P.W., Sadler, P.J., and Robinson, N.J. 2002. Multiple bacteria encode metallothioneins and SmtA-like zinc fingers. Mol. Microbiol. 45: 1421-1432.

Bonneau, R., Baliga, N.S., Deutsch, E.W., Shannon, P., and Hood, L. 2004. Comprehensive de novo structure prediction in a systems-biology context for the archaea Halobacterium sp. NRC-1. Genome Biol. 5: R52.

Bonneau, R., Reiss, D.J., Shannon, P., Facciotti, M., Hood, L., Baliga, N.S., and Thorsson, V. 2006. The Inferelator: An algorithm for learning parsimonious regulatory networks from systems-biology data sets de novo. Genome Biol. 7: R36.

Cavet, J.S., Meng, W., Pennella, M.A., Appelhoff, R.J., Giedroc, D.P., and Robinson, N.J. 2002. A nickel-cobalt-sensing ArsR-SmtB family repressor. Contributions of cytosol and effector binding sites to metal selectivity. J. Biol. Chem. 277: 38441-38448.

Chimienti, F., Jourdan, E., Favier, A., and Seve, M. 2001. Zinc resistance impairs sensitivity to oxidative stress in HeLa cells: Protection through metallothioneins expression. Free Radic. Biol. Med. 31: 1179-1190.

Cook, W.J., Kar, S.R., Taylor, K.B., and Hall, L.M. 1998. Crystal structure of the cyanobacterial metallothionein repressor SmtB: A model for metalloregulatory proteins. J. Mol. Biol. 275: 337-346.

Degtyarenko, K. 2000. Bioinorganic motifs: Towards functional classification of metalloproteins. Bioinformatics 16: 851-864.

Ercal, N., Gurer-Orhan, H., and Aykin-Burns, N. 2001. Toxic metals and oxidative stress part I: Mechanisms involved in metal-induced oxidative damage. Curr. Top. Med. Chem. 1: 529-539.

Ettema, T.J., Huynen, M.A., de Vos, W.M., and van der Oost, J. 2003. TRASH: A novel metal-binding domain predicted to be involved in heavy-metal sensing, trafficking and resistance. Trends Biochem. Sci. 28: $170-173$.

Facciotti, M.T., Bonneau, R., Hood, L., and Baliga, N.S. 2004. Systems biology experimental design-considerations for building predictive gene regulatory network models for prokaryotic systems. Curr. Genomics 5: 527-544.

Fellenberg, K., Hauser, N.C., Brors, B., Neutzner, A., Hoheisel, J.D., and Vingron, M. 2001. Correspondence analysis applied to microarray data. Proc. Natl. Acad. Sci. 98: 10781-10786.

Finney, L.A. and O'Halloran, T.V. 2003. Transition metal speciation in the cell: Insights from the chemistry of metal ion receptors. Science 300: 931-936.

Forbes, J.R., Hsi, G., and Cox, D.W. 1999. Role of the copper-binding domain in the copper transport function of ATP7B, the P-type ATPase defective in Wilson disease. J. Biol. Chem. 274: 12408-12413.

Gavella, M., Lipovac, V., Vucic, M., and Sverko, V. 1999. In vitro inhibition of superoxide anion production and superoxide dismutase activity by zinc in human spermatozoa. Int. J. Androl. 22: 266-274.

Grass, G. and Rensing, C. 2001. Genes involved in copper homeostasis in Escherichia coli. J. Bacteriol. 183: 2145-2147.

Guedon, E., Moore, C.M., Que, Q., Wang, T., Ye, R.W., and Helmann, J.D. 2003. The global transcriptional response of Bacillus subtilis to manganese involves the MntR, Fur, TnrA and $\sigma \mathrm{B}$ regulons. Mol. Microbiol. 49: 1477-1491.

Haber, F. and Weiss, J. 1934. The catalytic decomposition of hydrogen peroxide by iron salts. Proc. $R$. Soc. London, Ser. A. 147: 332-351.

Hamza, I., Schaefer, M., Klomp, L.W., and Gitlin, J.D. 1999. Interaction of the copper chaperone HAH1 with the Wilson disease protein is essential for copper homeostasis. Proc. Natl. Acad. Sci. 96: $13363-13368$.

Hantke, K. 2001. Iron and metal regulation in bacteria. Curr. Opin. Microbiol. 4: 172-177.

Hou, Z. and Mitra, B. 2003. The metal specificity and selectivity of ZntA from Escherichia coli using the acylphosphate intermediate. J. Biol. Chem. 278: 28455-28461.

Hung, I.H., Casareno, R.L., Labesse, G., Mathews, F.S., and Gitlin, J.D. 1998. HAH1 is a copper-binding protein with distinct amino acid residues mediating copper homeostasis and antioxidant defense. $J$. Biol. Chem. 273: 1749-1754.

Ideker, T., Thorsson, V., Siegel, A.F., and Hood, L.E. 2000. Testing for differentially-expressed genes by maximum-likelihood analysis of microarray data. J. Comput. Biol. 7: 805-817.

Ideker, T., Thorsson, V., Ranish, J.A., Christmas, R., Buhler, J., Eng, J.K., Bumgarner, R., Goodlett, D.R., Aebersold, R., and Hood, L. 2001. Integrated genomic and proteomic analyses of a systematically perturbed metabolic network. Science 292: 929-934.

Jakubovics, N.S. and Jenkinson, H.F. 2001. Out of the iron age: New insights into the critical role of manganese homeostasis in bacteria. Microbiol. 147: 1709-1718.

Jensen, L.T., Ajua-Alemanji, M., and Culotta, V.C. 2003. The Saccharomyces cerevisiae high affinity phosphate transporter encoded by PHO84 also functions in manganese homeostasis. J. Biol. Chem. 278: 42036-42040.

Jordan, I.K., Natale, D.A., Koonin, E.V., and Galperin, M.Y. 2001. Independent evolution of heavy metal-associated domains in copper chaperones and copper-transporting atpases. J. Mol. Evol. 53: $622-633$.

Kanehisa, M. 2002. The KEGG database. Novartis Found. Symp. 247: 91-101; discussion 101-103, 119-128, 244-252.

Kehrer, J.P. 2000. The Haber-Weiss reaction and mechanisms of toxicity. Toxicology 149: 43-50.

Kennedy, S.P., Ng, W.V., Salzberg, S.L., Hood, L., and DasSarma, S. 2001 Understanding the adaptation of Halobacterium species $N R C-1$ to its extreme environment through computational analysis of its genome sequence. Genome Res. 11: 1641-1650.

Kirschner, M.W. 2005. The meaning of systems biology. Cell 121: $503-504$

Larin, D., Mekios, C., Das, K., Ross, B., Yang, A.S., and Gilliam, T.C. 1999. Characterization of the interaction between the Wilson and 
Menkes disease proteins and the cytoplasmic copper chaperone, HAH1p. J. Biol. Chem. 274: 28497-28504.

Lin, S.J., Pufahl, R.A., Dancis, A., O'Halloran, T.V., and Culotta, V.C. 1997. A role for the Saccharomyces cerevisiae ATX1 gene in copper trafficking and iron transport. J. Biol. Chem. 272: 9215-9220.

Medicis, E.D., Paquette, J., Gauthier, J.J., and Shapcott, D. 1986. Magnesium and manganese content of halophilic bacteria. Appl. Environ. Microbiol. 52: 567-573.

Mittler, R. 2002. Oxidative stress, antioxidants and stress tolerance. Trends Plant Sci. 7: 405-410.

Moore, C.M., Gaballa, A., Hui, M., Ye, R.W., and Helmann, J.D. 2005. Genetic and physiological responses of Bacillus subtilis to metal ion stress. Mol. Microbiol. 57: 27-40.

Moreno-Hagelsieb, G. and Collado-Vides, J. 2002. A powerful non-homology method for the prediction of operons in prokaryotes. Bioinformatics (Suppl 1) 18: S329-S336.

Munro, H.N. and Linder, M.C. 1978. Ferritin: Structure, biosynthesis, and role in iron metabolism. Physiol. Rev. 58: 317-396.

Nair, S. and Finkel, S.E. 2004. Dps protects cells against multiple stresses during stationary phase. J. Bacteriol. 186: 4192-4198.

Nelson, N. 1999. Metal ion transporters and homeostasis. EMBO J. 18: $4361-4371$.

Ng, W.V., Kennedy, S.P., Mahairas, G.G., Berquist, B., Pan, M., Shukla, H.D., Lasky, S.R., Baliga, N.S., Thorsson, V., Sbrogna, J., et al. 2000. From the cover: Genome sequence of Halobacterium species NRC-1. Proc. Natl. Acad. Sci. 97: 12176-12181.

Nieto, J.J., Fernandez-Castillo, R., Marquez, M.C., Ventosa, A., Quesada, E., and Ruiz-Berraquero, F. 1989. Survey of metal tolerance in moderately halophilic eubacteria. Appl. Environ. Microbiol. 55: $2385-2390$.

O'Halloran, T.V. 1993. Transition metals in control of gene expression. Science 261: 715-725.

Outten, C.E. and O'Halloran, T.V. 2001. Femtomolar sensitivity of metalloregulatory proteins controlling zinc homeostasis. Science 292: 2488-2492.

Overbeek, R., Fonstein, M., D'Souza, M., Pusch, G.D., and Maltsev, N. 1999. The use of gene clusters to infer functional coupling. Proc. Natl. Acad. Sci. 96: 2896-2901.

Patzer, S.I. and Hantke, K. 1998. The ZnuABC high-affinity zinc uptake system and its regulator Zur in Escherichia coli. Mol. Microbiol. 28: 1199-1210.

Pellegrini, M., Marcotte, E.M., Thompson, M.J., Eisenberg, D., and Yeates, T.O. 1999. Assigning protein functions by comparative genome analysis: Protein phylogenetic profiles. Proc. Natl. Acad. Sci. 96: $4285-4288$.

Que, Q. and Helmann, J.D. 2000. Manganese homeostasis in Bacillus subtilis is regulated by MntR, a bifunctional regulator related to the diphtheria toxin repressor family of proteins. Mol. Microbiol. 35: $1454-1468$.

Raab, A. and Feldmann, J. 2003. Microbial transformation of metals and metalloids. Sci. Prog. 86: 179-202.

Reindel, S., Anemuller, S., Sawaryn, A., and Matzanke, B.F. 2002. The DpsA-homologue of the archaeon Halobacterium salinarum is a ferritin. Biochim. Biophys. Acta 1598: 140-146.

Reindel, S., Schmidt, C.L., Anemuller, S., and Matzanke, B.F. 2005. Expression and regulation pattern of ferritin-like DpsA in the archaeon Halobacterium Salinarum. Biometals 18: 387-397.

Rensing, C., Mitra, B., and Rosen, B.P. 1997. The zntA gene of Escherichia coli encodes a $\mathrm{Zn}(\mathrm{II})$-translocating P-type ATPase. Proc. Natl. Acad. Sci. 94: 14326-14331.

Rensing, C., Sun, Y., Mitra, B., and Rosen, B.P. 1998. Pb(II)-translocating P-type ATPases. J. Biol. Chem. 273: 32614-32617.

Rensing, C., Ghosh, M., and Rosen, B.P. 1999. Families of soft-metal-ion-transporting ATPases. J. Bacteriol. 181: 5891-5897.

Schelert, J., Dixit, V., Hoang, V., Simbahan, J., Drozda, M., and Blum, P. 2004. Occurrence and characterization of mercury resistance in the hyperthermophilic archaeon Sulfolobus solfataricus by use of gene disruption. J. Bacteriol. 186: 427-437.
Shannon, P.T., Reiss, D.J., Bonneau, R., and Baliga, N.S. 2006. Gaggle: An open-source software system for integrating bioinformatics software and data sources. BMC Bioinformatics 7: 176.

Sharma, R., Rensing, C., Rosen, B.P., and Mitra, B. 2000. The ATP hydrolytic activity of purified ZntA, a

$\mathrm{Pb}(\mathrm{II}) / \mathrm{Cd}(\mathrm{II}) / \mathrm{Zn}$ (II)-translocating ATPase from Escherichia coli. J. Biol. Chem. 275: 3873-3878.

Silver, S. 1992. Plasmid-determined metal resistance mechanisms: Range and overview. Plasmid 27: 1-3.

Strausak, D., Mercer, J.F., Dieter, H.H., Stremmel, W., and Multhaup, G. 2001. Copper in disorders with neurological symptoms: Alzheimer's, Menkes, and Wilson diseases. Brain Res. Bull. 55: 175-185.

Sunkar, R., Bartels, D., and Kirch, H.H. 2003. Overexpression of a stress-inducible aldehyde dehydrogenase gene from Arabidopsis thaliana in transgenic plants improves stress tolerance. Plant J. 35: $452-464$.

Sussman, J.L., Lin, D., Jiang, J., Manning, N.O., Prilusky, J., Ritter, O., and Abola, E.E. 1998. Protein Data Bank (PDB): Database of three-dimensional structural information of biological macromolecules. Acta Crystallogr. D Biol. Crystallogr. 54: 1078-1084.

Takeyama, Y., Ogino, K., Segawa, H., Kobayashi, H., Uda, T., and Houbara, T. 1995. Effects of zinc on production of active oxygen species by rat neutrophils. Pharmacol. Toxicol. 76: 50-55.

Tatusov, R.L., Galperin, M.Y., Natale, D.A., and Koonin, E.V. 2000. The COG database: A tool for genome-scale analysis of protein functions and evolution. Nucleic Acids Res. 28: 33-36.

Theil, E.C. 1987. Ferritin: Structure, gene regulation, and cellular function in animals, plants, and microorganisms. Annu. Rev. Biochem. 56: 289-315.

Torriglia, A., Chaudun, E., Courtois, Y., and Counis, M.F. 1997. On the use of $\mathrm{Zn}^{2+}$ to discriminate endonucleases activated during apoptosis. Biochimie 79: 435-438.

Tottey, S., Rondet, S.A., Borrelly, G.P., Robinson, P.J., Rich, P.R., and Robinson, N.J. 2002. A copper metallochaperone for photosynthesis and respiration reveals metal-specific targets, interaction with an importer, and alternative sites for copper acquisition. J. Biol. Chem. 277: 5490-5497.

Tottey, S., Harvie, D.R., and Robinson, N.J. 2005. Understanding how cells allocate metals using metal sensors and metallochaperones. Acc. Chem. Res. 38: 775-783.

Tusher, V.G., Tibshirani, R., and Chu, G. 2001. Significance analysis of microarrays applied to the ionizing radiation response. Proc. Natl. Acad. Sci. 98: 5116-5121.

Valko, M., Morris, H., and Cronin, M.T. 2005. Metals, toxicity and oxidative stress. Curr. Med. Chem. 12: 1161-1208.

Wang, G., Kennedy, S.P., Fasiludeen, S., Rensing, C., and DasSarma, S. 2004. Arsenic resistance in Halobacterium sp. strain NRC-1 examined by using an improved gene knockout system. J. Bacteriol. 186: $3187-3194$.

Weston, A.D., Baliga, N.S., Bonneau, R., and Hood, L. 2003. Systems approaches applied to the study of Saccharomyces cerevisiae and Halobacterium sp. Cold Spring Harb. Symp. Quant. Biol. 68: 345-357.

Wiedenheft, B., Mosolf, J., Willits, D., Yeager, M., Dryden, K.A., Young, M., and Douglas, T. 2005. An archaeal antioxidant: Characterization of a Dps-like protein from Sulfolobus solfataricus. Proc. Natl. Acad. Sci. 102: 10551-10556.

Winkelmann, G. 2002. Microbial siderophore-mediated transport. Biochem. Soc. Trans. 30: 691-696.

Winterbourn, C.C. 1995. Toxicity of iron and hydrogen peroxide: The Fenton reaction. Toxicol. Lett. 82-83: 969-974.

Zeth, K., Offermann, S., Essen, L.O., and Oesterhelt, D. 2004. Iron-oxo clusters biomineralizing on protein surfaces: Structural analysis of Halobacterium salinarum DpsA in its low- and high-iron states. Proc. Natl. Acad. Sci. 101: 13780-13785.

Received February 1, 2006; accepted in revised form April 18, 2006. 


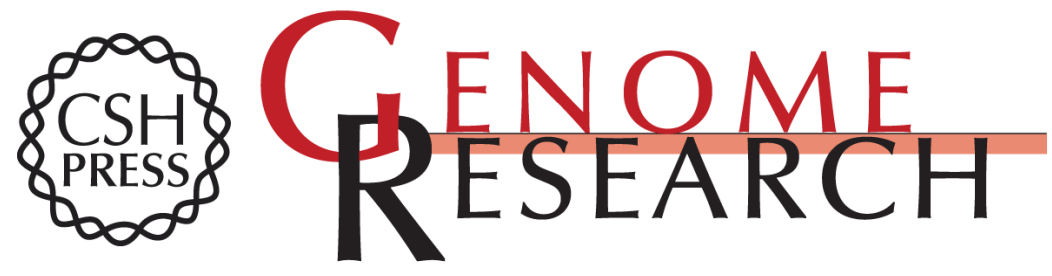

\section{A systems view of haloarchaeal strategies to withstand stress from transition metals}

Amardeep Kaur, Min Pan, Megan Meislin, et al.

Genome Res. 2006 16: 841-854

Access the most recent version at doi:10.1101/gr.5189606

Supplemental Material

References

License

Email Alerting Service
http://genome.cshlp.org/content/suppl/2006/06/06/gr.5189606.DC1

This article cites 82 articles, 34 of which can be accessed free at: http://genome.cshlp.org/content/16/7/841.full.html\#ref-list-1

Receive free email alerts when new articles cite this article - sign up in the box at the top right corner of the article or click here.

\section{Affordable, Accurate Sequencing.}

To subscribe to Genome Research go to:

https://genome.cshlp.org/subscriptions 